\title{
Práticas turísticas por meio da análise da dimensão ambiental em geossítios do Projeto Geoparque Seridó (RN)
}

\section{Touristical pratices through the environmental dimension analysis in geosites of Seridó Geopark Project (RB, Brazil)}

\author{
Janaína Luciana de Medeiros, Marcos Antonio Leite do Nascimento, \\ André Riani Costa Perinotto
}

\begin{abstract}
RESUMO
O presente estudo analisou a situação ambiental nos diferentes geossítios do Projeto Geoparque Seridó visando uma prática turística de forma sustentável. Para tanto, se utilizou da avaliação na dimensão ambiental da sustentabilidade dos geossítios lançando mão do modelo proposto por Falcão (2010). A natureza desse trabalho foi exploratória com base descritiva das características obtidas por meio do método da observação das localidades selecionadas. Quanto aos meios, o trabalho foi de campo, com aplicação de entrevistas semiestruturadas com os condutores e guias de turismo, bem como com representantes das secretarias de turismo e meio ambiente dos municípios de Cerro Corá, Lagoa Nova, Currais Novos, Acari, Carnaúba dos Dantas e Parelhas. Concluiu-se, porquanto, que os geossítios estudados possuem potencial para o turismo ou pelo menos estão caminhando em direção ao desenvolvimento turístico nesta Região. Diante do exposto, a região estudada apresenta problemas no que tange a conservação dos geossítios, assim como, a falta de consciência ambiental. Ficando evidenciado pela ausência de investimentos por parte dos órgãos responsáveis e a falta de consciência da importância da área também das populações locais e dos visitantes que utilizam seus recursos de forma inadequada. Igualmente, vale inferir que a pesquisa contribuirá para novos olhares com relação à aplicabilidade da educação ambiental na Região do Seridó do Rio Grande do Norte, especificamente ao que tange aos seis municípios supracitados.
\end{abstract}

PALAVRAS-CHAVE: Turismo; Dimensão Ambiental; Projeto Geoparque Seridó. 


\section{ABSTRACT}

This study analyzed the environmental situation in different geosites of Geopark Seridó Project aiming a touristic practice in a sustainable manner. Therefore, it was used the evaluation in the environmental dimension of sustainability of geosites making use of the model proposed by Falcon (2010). The nature of this work was exploratory with descriptive basis of the characteristics obtained by the method of observation of the selected locations. As for the means, the work was a field one, with application of semi-structured interviews with conductors and tour guides, as well as representatives of tourism and environment departments of the municipalities of Cerro Corá, Lagoa Nova, Currais Novos, Acari, Carnaúba dos Dantas and Parelhas. It was concluded, inasmuch as, that the studied geosites have potential for tourism or at least are moving towards touristic development in this Region. Given the above, the region studied presents problems regarding the conservation of geosites, as well as the lack of environmental awareness. It's evidenced by the lack of investment by the responsible bodies and the absence of awareness of the importance of the area for the local population and visitors who use its resources inappropriately. Also, it's worth infer that the research will contribute to new insights regarding the applicability of environmental education in the Seridó region of Rio Grande do Norte, specifically when it comes to the six aforementioned municipalities.

KEYWORDS: Tourism; Environmental Dimension; Seridó Geopark Project.

\section{Introdução}

À medida que os países crescem economicamente observam-se melhorias na qualidade de vida, educação, saúde, melhores condições no trabalho, entre outros. Porém, o crescimento econômico gera inúmeros custos, tais como a diminuição dos recursos, desequilíbrios ecológicos e a degradação ambiental.

Os questionamentos sobre como solucionar os problemas ambientais da atualidade estão conduzindo a novos segmentos e concepções de desenvolvimento, entre os quais se destaca a proposta de desenvolvimento sustentável (BUARQUE, 2004).

Quando se pensa em conservação da natureza, são comuns pesquisas relacionadas à proteção de espécies. Entretanto, é necessário pensar nos componentes dos sistemas ecológicos, tanto a biodiversidade (meio biótico) quanto à geodiversidade (meio abiótico) para que se obter uma visão holística dos fenômenos a serem pesquisados.

O presente artigo foca nos aspectos referentes à situação ambiental de geossítios e contribuem com o debate sobre a aplicabilidade da educação ambiental na região do Projeto Geoparque Seridó, especificamente nos municípios de Cerro Corá, Lagoa Nova, Currais Novos, Acari, Carnaúba dos Dantas e Parelhas (Figura 1). Tais municípios apresentam, de acordo com Nascimento e Ferreira (2012), um dos mais completos dentre o patrimônio geológico encontrado no Nordeste do Brasil, sendo decorrente de inúmeros processos naturais na qual a região foi submetida ao longo do Tempo Geológico. 
Esses seis municípios supracitados fazem parte do Seridó Potiguar, localizados na Mesorregião Central do Rio Grande do Norte, onde o acesso a partir de Natal, capital do Estado do Rio Grande do Norte, se dá pela BR226 até a cidade de Currais Novos, tomando-se em seguida inúmeras outras rodovias (BR-104 e BR-427) e (RN-087 e RN-288) para ter acesso aos demais municípios da área (Figura 1).

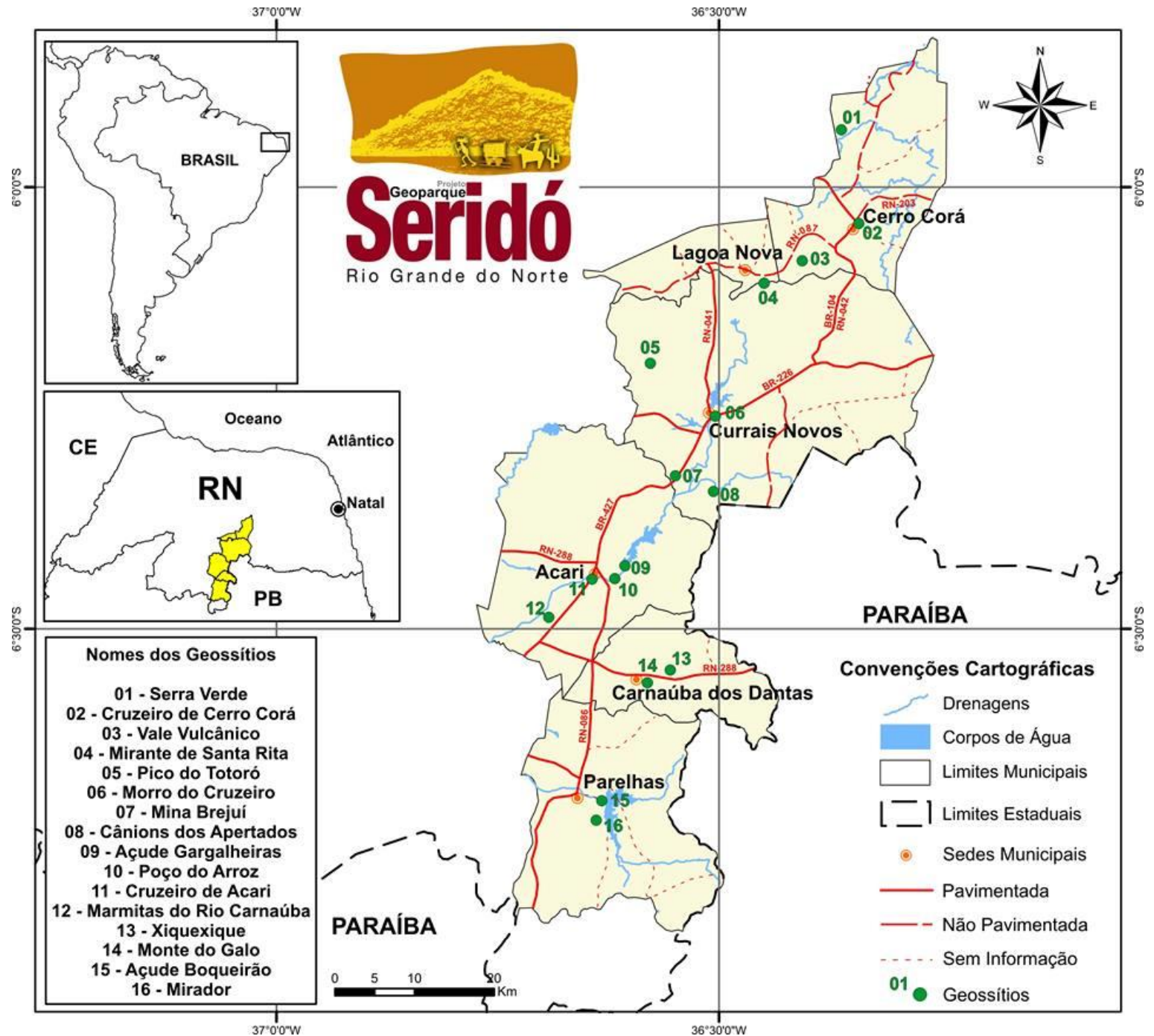

Figura 1: Mapa de localização dos municípios do Projeto Geoparque Seridó e seus geossítios.

Figure 1: Location Map of municipalities of Geoparque Seridó Project and its geosites.

\section{Materiais e métodos}

Neste estudo foi realizado a obtenção de dados por pesquisa documental sobre os municípios que fazem parte do Projeto Geoparque Seridó de forma a melhor compreender a realidade de uso turística dos geossítios baseando-se nos conceitos direcionados para a prática sustentável como ferramenta de implementação do turismo, tendo como natureza exploratória com base descritiva das características obtidas por meio do método da observação das localidades selecionadas a serem objetos de estudo. 
Quanto aos meios, o trabalho foi de campo, com a aplicação de entrevista com os representantes das secretarias de turismo e de meio ambiente do seis municípios do Projeto Geoparque Seridó, assim como guias locais e de turismo, com a finalidade de obter informações que proporcionaram maior conhecimento sobre o objeto da pesquisa, bem como também representantes das comunidades nos quais estão inseridos os geossítios que foram estudados. Com isso, esses dados serviram para a realização da análise do nível da dimensão ambiental da sustentabilidade por meio do método desenvolvido por Falcão (2010).

\section{Sustentabilidade: dimensões e análises}

\section{As dimensões da sustentabilidade}

Sendo muito utilizado para fazer referências às diversas formas de se manter a proteção ambiental, o termo sustentabilidade seria uma resposta às necessidades humanas, com ou sem custo de produção e consumo para outras pessoas ou ecossistemas hoje e no futuro.

A ideia de sustentabilidade contradiz com o termo desenvolvimento sustentável, permeando todos os diagnósticos e as propostas de solução de praticamente todos os aspectos que compõem a questão ambiental não podendo haver, segundo Bezerra et al. (2011, p.101) "[...] desenvolvimento, crescimento econômico de modo a gerar na natureza sobrecargas insustentáveis para a vida em geral e para o próprio processo econômico que se alimenta de recursos naturais".

O termo sustentabilidade significa, por conseguinte, a possibilidade continuamente de obter condições iguais ou superiores de vida em dado ecossistema, onde "a sustentabilidade relaciona-se com a melhor qualidade de vida das populações, a partir da capacidade de suporte dos ecossistemas" (MARTINS; CÂNDIDO 2010).

Essa complexidade existente nas interações entre sistemas humanos e sistemas ambientais faz com que esse debate seja amplo e multidisciplinar, necessitando de um "alcance de resultados realmente sustentáveis sob a ótica social, ambiental, demográfica, política, econômica, cultural e institucional' (MARTINS; CÂNDIDO 2010).

Nessa premissa, o homem precisa da ocupação e de exploração do espaço para a satisfação de suas necessidades mínimas (BENI 2006), mas deve existir um conjunto de objetivos definidos socialmente e com visão no futuro (SACHS 2009). Baseado nesse conjunto de objetivos, Sachs (1993 apud BENI 2006, p.126), organizou as dimensões da sustentabilidade, conforme exposto abaixo:

- Sustentabilidade social: É a criação de um processo de desenvolvimento civilizatório baseado no ser, que seja sustentado por maior equidade na distribuição do ter, nos direitos e nas condições das amplas massas da população, e que diminua a distância entre os padrões de vida dos mais ricos e dos mais pobres.

- Sustentabilidade econômica: Possibilita melhor alocação e gestão mais eficiente dos recursos, por um fluxo regular do investimento público e 
privado. Essa eficiência é macrossocial, reduzindo os custos sociais e ambientais bem diferentes da lógica economista.

- Sustentabilidade ecológica: Incrementa o aumento da capacidade de recursos naturais, limitando os recursos não renováveis ou ambientalmente prejudiciais, reduzindo o volume de poluição, autolimitando o consumo material pelas camadas sociais mais privilegiadas, intensificando a pesquisa de tecnologias limpas e definindo regras para uma adequada proteção ambiental.

- Sustentabilidade espacial: É aquela voltada a uma configuração rural-urbana mais equilibrada com ênfase nas seguintes questões: concentração excessiva nas áreas urbanas, processos de colonização descontrolados, promoção de projetos modernos de agricultura regenerativa e agro florestamento, industrialização centralizada, criação de empregos rurais não agrícolas e o estabelecimento de uma rede de reservas naturais e de biosfera para proteger a biodiversidade.

- Sustentabilidade política: Privilegia a negociação da diversidade de interesses envolvidos em questões fundamentais desde o âmbito local até o global.

Beni (2006) expõe, porquanto, mais uma dimensão da sustentabilidade, a institucional que "integra e permeia os anteriores cenários de sustentabilidade e, com eles, constrói o sistema de governança compartilhada regional, formando o modelo de gestão aplicável ao território".

\section{A criteriorização da dimensão ambiental da sustentabilidade por Falcão (2010)}

Diante dos acontecimentos atuais, a degradação ambiental se configura como uma das principais preocupações nas discussões mundiais, e assim "a dimensão ambiental torna-se uma questão que envolve um conjunto de atores que fazem parte das inter-relações do meio natural com o social' (FALCÃO 2010, p.56).

Para Foladori (2005) existem três principais interpretações envolvendo as causas da degradação ambiental que seriam tecnologias ineficientes, consumismo, pobreza, exigindo assim, diferentes políticas para a diminuição de consequências ambientais, sendo a primeira e a segunda focadas em aspectos técnicos, ou seja, em investimentos em ciência e tecnologia que possam minimizar impactos negativos ao meio ambiente.

Vale mencionar, por conseguinte, que nesta pesquisa ocorreu a análise da dimensão ambiental da sustentabilidade proposto por Falcão (2010), a qual fez a adaptação do TALC - Modelo de Ciclo de Vida de destinos turísticos proposto por Butler em 1980, e sua ideia central é a possibilidade de identificar o estágio de desenvolvimento de um determinado destino a partir de seis fases distintas. Assim, o TALC sublinha a necessidade de um planejamento estratégico e proativo que forneça base para uma tomada de decisão estratégica (FALCÃO, 2010) às dimensões da sustentabilidade, estabelecendo 14 indicadores e 43 
critérios de análise para avaliação das dimensões da sustentabilidade, ao ponto que, além do conjunto de indicadores para cada dimensão, propôs critérios de análise ou sub-indicadores que servem de base para 0 delineamento de cada indicador, como também foram construídas matrizes de parâmetros para avaliação dos critérios de análise.

Ressalta-se ainda, que os três indicadores propostos por Falcão (2010) para delinear os critérios de análise da dimensão ambiental foram baseados numa discussão teórica acerca de Delamaro et al. (2002), Jacobi (2003), Foladori (2005), Beni (2006) e Bartholo (2009), contemplando aspectos relacionados à educação ambiental, proteção do produto turístico e gestão do meio ambiente. O Quadro 1 exibe a dimensão ambiental da sustentabilidade com seus respectivos indicadores e os critérios de análise para a avaliação dessa dimensão.

Quadro 1: Dimensão ambiental da sustentabilidade.

Table 1: Environment dimension of sustainability.

\begin{tabular}{|l|l|}
\hline \multicolumn{1}{|c|}{ Indicadores } & \multicolumn{1}{c|}{ Critérios } \\
\hline Educação ambiental & $\begin{array}{l}\text { •Acesso da comunidade à educação ambiental } \\
\text {-Valorização do patrimônio ambiental }\end{array}$ \\
\hline $\begin{array}{l}\text { Conservação e proteção do } \\
\text { produto turístico }\end{array}$ & $\begin{array}{l}\text {-Preservação dos recursos naturais } \\
\text { •-Capacidade de carga dos atrativos naturais* } \\
\text {-Poluição visual } \\
\text {-Poluição sonora }\end{array}$ \\
\hline Gestão do meio ambiente & $\begin{array}{l}\text {-Preparação às emergências ambientais } \\
\text {-Gestão dos resíduos sólidos } \\
\text {-Gestão da energia* } \\
\text { •Conservação e gestão do uso da água } \\
\text { •Saneamento e gestão dos recursos hídricos }\end{array}$ \\
\hline
\end{tabular}

Fonte: Adaptado de Falcão (2010). *Critérios não utilizados nesse artigo.

Source: Adapted from Falcão (2010). *Criteria not used in this paper.

Em relação ao indicador educação ambiental, tem-se dois critérios: - acesso da comunidade à educação ambiental e a valorização do patrimônio ambiental. Falcão (2010) seguiu recomendações de Jacobi (2003), sobre transformação das relações entre natureza, técnica e cultura a partir de um processo interdisciplinar fornecido pelos sistemas de conhecimento da sociedade. A elaboração da matriz de parâmetros para avaliação desses critérios é apresentado no Quadro 2.

No que tange ao critério "Acesso da comunidade à educação ambiental", os aspectos avaliados consistem nas ações realizadas no destino turístico voltados para a educação ambiental e a articulação dos centros de ensino com tais atividades. Sobre o critério "valorização do patrimônio ambiental", busca-se identificar como se dá a promoção do meio ambiente em um destino e como estão articulados os atores locais em prol da proteção ambiental desse destino (FALCÃO, 2010). 
Quadro 2: Matriz de parâmetros para indicador educação ambiental.

Table 2: Matrix parameters for environmental education indicator.

\begin{tabular}{|c|c|c|c|c|}
\hline \multicolumn{5}{|c|}{ EDUCAÇÃO AMBIENTAL } \\
\hline \multirow[t]{2}{*}{ Parâmetros } & \multicolumn{4}{|c|}{ Pesos } \\
\hline & Inexistente & Fraco & Moderado & Forte \\
\hline $\begin{array}{l}\text { Acesso da } \\
\text { comunidade } \\
\text { à educação } \\
\text { ambiental }\end{array}$ & $\begin{array}{c}\text { Não há } \\
\text { eventos } \\
\text { disponíveis } \\
\text { para a } \\
\text { comunidade } \\
\text { que abordem } \\
\text { a questão } \\
\text { ambiental } \\
\text { nem há a } \\
\text { participação } \\
\text { das escolas } \\
\text { na causa }\end{array}$ & $\begin{array}{c}\text { Há eventos } \\
\text { esporádicos } \\
\text { sobre o meio } \\
\text { ambiente, mas } \\
\text { não há } \\
\text { articulação das } \\
\text { escolas para } \\
\text { exercer um } \\
\text { trabalho } \\
\text { paralelo }\end{array}$ & $\begin{array}{c}\text { Há eventos } \\
\text { esporádicos } \\
\text { sobre o meio } \\
\text { ambiente e as } \\
\text { escolas } \\
\text { participam }\end{array}$ & $\begin{array}{c}\text { Há eventos } \\
\text { gratuitos } \\
\text { regularmente que } \\
\text { tratam de } \\
\text { assuntos } \\
\text { relacionados ao } \\
\text { meio ambiente do } \\
\text { local, além da } \\
\text { articulação e } \\
\text { participação das } \\
\text { escolas nesses } \\
\text { eventos }\end{array}$ \\
\hline $\begin{array}{c}\text { Valorização } \\
\text { do } \\
\text { patrimônio } \\
\text { ambiental }\end{array}$ & $\begin{array}{c}\text { Não há } \\
\text { eventos, } \\
\text { ações, } \\
\text { projetos e ou } \\
\text { campanhas } \\
\text { disponíveis } \\
\text { para a } \\
\text { comunidade } \\
\text { que } \\
\text { promovam o } \\
\text { meio } \\
\text { ambiente }\end{array}$ & $\begin{array}{l}\text { A promoção do } \\
\text { meio ambiente } \\
\text { não consegue } \\
\text { retratar a } \\
\text { realidade nem } \\
\text { mobilizar a } \\
\text { população para } \\
\text { a importância } \\
\text { da preservação } \\
\text { dos recursos } \\
\text { naturais }\end{array}$ & $\begin{array}{l}\text { A promoção do } \\
\text { meio ambiente } \\
\text { consegue } \\
\text { mobilizar a } \\
\text { população sobre } \\
\text { a importância da } \\
\text { preservação dos } \\
\text { recursos } \\
\text { naturais, porém, } \\
\text { a ausência de } \\
\text { recursos limitam } \\
\text { projetos mais } \\
\text { eficazes }\end{array}$ & $\begin{array}{l}\text { A promoção do } \\
\text { meio ambiente se } \\
\text { dá a partir de } \\
\text { ações, projetos e } \\
\text { campanhas que } \\
\text { além de mobilizar } \\
\text { a população, } \\
\text { promovem a } \\
\text { articulação da } \\
\text { comunidade em } \\
\text { prol do meio } \\
\text { ambiente }\end{array}$ \\
\hline
\end{tabular}

Fonte: Adaptado de Falcão (2010).

Source: Adapted from Falcão (2010).

O segundo indicador da dimensão ambiental da sustentabilidade proposto por Falcão (2010) é o da conservação e preservação do produto turístico, onde possui um grupo de quatro critérios de análise, sendo eles: a preservação dos recursos naturais; a capacidade de carga dos atrativos naturais; poluição visual; e poluição sonora, expostos no Quadro 3 (próxima página).

Diante dos dados supracitados, o critério de "Preservação dos recursos naturais" de um destino turístico, segundo Beni (2006), deve compreender não só a sustentabilidade ambiental do local como também a própria preservação do produto turístico quando este tem seu foco nos atrativos naturais do destino.

Já para o critério "Capacidade de carga dos atrativos naturais", considera-se uma das principais ferramentas para garantir a manutenção de bons estados de conservação dos atrativos turísticos, além de preservar tais atrativos e equilibrar a capacidade de depuração dos ecossistemas. Dessa forma, esse critério de análise se considera a existência ou não de metodologias de capacidade de carga no destino turístico (BENI 2006; FALCÃO, 2010). 
Quadro 3: Matriz de parâmetros para indicador conservação e proteção do produto turístico.

Table 3: Matrix indicator parameters for conservation and protection of the tourism product.

\begin{tabular}{|c|c|c|c|c|}
\hline \multicolumn{5}{|c|}{ CONSERVAÇÃO E PROTEÇÃO DO PRODUTO TURÍSTICO } \\
\hline \multirow[t]{2}{*}{ Parâmetros } & \multicolumn{4}{|c|}{ Pesos } \\
\hline & Inexistente & Fraco & Moderado & Forte \\
\hline $\begin{array}{c}\text { Preservação } \\
\text { dos } \\
\text { recursos } \\
\text { naturais }\end{array}$ & $\begin{array}{l}\text { Inexistência de } \\
\text { fiscalização } \\
\text { quanto ao } \\
\text { cumprimento da } \\
\text { legislação } \\
\text { ambiental pelos } \\
\text { empreendimentos }\end{array}$ & $\begin{array}{c}\text { Possui } \\
\text { fiscalização } \\
\text { da legislação } \\
\text { ambiental, } \\
\text { porém } \\
\text { observa-se } \\
\text { fragilidades } \\
\text { quanto a } \\
\text { pressão para } \\
\text { construção de } \\
\text { propriedades } \\
\text { privadas em } \\
\text { áreas naturais }\end{array}$ & $\begin{array}{c}\text { Possui } \\
\text { fiscalização da } \\
\text { legislação } \\
\text { ambiental, } \\
\text { porém } \\
\text { observa-se } \\
\text { fragilidades } \\
\text { quanto à } \\
\text { pressão para } \\
\text { construção de } \\
\text { propriedades } \\
\text { privadas em } \\
\text { áreas naturais }\end{array}$ & $\begin{array}{c}\text { Possui } \\
\text { fiscalização } \\
\text { intensa do } \\
\text { cumprimento da } \\
\text { legislação } \\
\text { ambiental, } \\
\text { ausência de } \\
\text { fragilidades } \\
\text { quanto às } \\
\text { pressões para } \\
\text { construção de } \\
\text { propriedades } \\
\text { privadas em } \\
\text { áreas naturais e } \\
\text { participação da } \\
\text { população na } \\
\text { gestão de áreas } \\
\text { protegidas }\end{array}$ \\
\hline $\begin{array}{c}\text { Capacidade } \\
\text { de carga } \\
\text { dos } \\
\text { atrativos } \\
\text { naturais }\end{array}$ & $\begin{array}{l}\text { Inexistência de } \\
\text { metodologia de } \\
\text { capacidade de } \\
\text { carga dos } \\
\text { atrativos naturais }\end{array}$ & $\begin{array}{l}\text { Existência da } \\
\text { metodologia, } \\
\text { porém não é } \\
\text { respeitada } \\
\text { pela gestão e } \\
\text { atores locais } \\
\text { do destino }\end{array}$ & $\begin{array}{c}\text { Existência da } \\
\text { metodologia } \\
\text { de capacidade } \\
\text { de carga, esta } \\
\text { é respeitada a } \\
\text { partir do } \\
\text { controle do } \\
\text { número de } \\
\text { visitantes nos } \\
\text { atrativos } \\
\text { naturais mais } \\
\text { impactados }\end{array}$ & $\begin{array}{c}\text { Existência da } \\
\text { metodologia de } \\
\text { capacidade de } \\
\text { carga, é } \\
\text { respeitada, } \\
\text { possui controle } \\
\text { do número de } \\
\text { visitantes, além } \\
\text { de campanhas } \\
\text { informacionais } \\
\text { constantes sobre } \\
\text { a situação dos } \\
\text { atrativos naturais }\end{array}$ \\
\hline $\begin{array}{c}\text { Poluição } \\
\text { visual }\end{array}$ & $\begin{array}{l}\text { A poluição visual } \\
\text { compromete } \\
\text { totalmente a } \\
\text { paisagem do } \\
\text { destino, } \\
\text { principalmente os } \\
\text { atrativos naturais }\end{array}$ & $\begin{array}{c}\text { A poluição } \\
\text { visual existe, } \\
\text { compromete } \\
\text { principalmente } \\
\text { o centro } \\
\text { urbano e os } \\
\text { atrativos } \\
\text { naturais do } \\
\text { destino }\end{array}$ & $\begin{array}{c}\text { A poluição } \\
\text { visual existe, } \\
\text { compromete o } \\
\text { centro urbano } \\
\text { e com menor } \\
\text { intensidade } \\
\text { alguns } \\
\text { atrativos } \\
\text { naturais do } \\
\text { destino }\end{array}$ & $\begin{array}{l}\text { A poluição visual } \\
\text { não compromete } \\
\text { as paisagens do } \\
\text { destino }\end{array}$ \\
\hline $\begin{array}{c}\text { Poluição } \\
\text { sonora }\end{array}$ & $\begin{array}{c}\text { A poluição } \\
\text { sonora } \\
\text { compromete } \\
\text { totalmente a } \\
\text { tranquilidade do } \\
\text { destino }\end{array}$ & $\begin{array}{l}\text { A poluição } \\
\text { sonora } \\
\text { compromete o } \\
\text { centro urbano } \\
\text { do destino e } \\
\text { arredores }\end{array}$ & $\begin{array}{l}\text { A poluição } \\
\text { sonora } \\
\text { compromete } \\
\text { apenas o } \\
\text { centro urbano } \\
\text { do destino }\end{array}$ & $\begin{array}{c}\text { Não há } \\
\text { problemas com } \\
\text { poluição sonora } \\
\text { no destino }\end{array}$ \\
\hline
\end{tabular}

Fonte: Adaptado de Falcão (2010).

Source: Adapted from Falcão (2010). 
O critério "Poluição visual" pode prejudicar a paisagem de diversos destinos turísticos, se tornando importante buscar uma identidade visual e combater dimensionamentos, iluminação, propagandas e sinalização que desarmonizem o lugar. Esse critério procura perceber se existe poluição visual em um destino e quais os lugares mais afetados, com intuito de entender se os atrativos naturais apresentam ou não esse tipo de poluição (FALCÃO, 2010).

A "Poluição sonora" torna-se, nesta perspectiva, um importante critério, já que o silêncio e a harmonia é uma das condições mais procuradas por quem busca lazer e descanso. Diante disso, esse critério objetiva identificar os locais nos quais a intensidade de ruídos pode comprometer a permanência dos turistas no destino (BENI 2006; FALCÃO, 2010).

No Quadro 4 (próxima página) encontram-se os cinco critérios de análise do indicador "gestão do meio ambiente", onde buscam saber: a preparação do destino às emergências ambientais; gestão dos resíduos sólidos; gestão da energia; conservação e gestão do uso da água; e saneamento e gestão dos recursos hídricos.

O critério "Preparação às emergências ambientais" é, pois, considerada como o grau de preparação de um determinado destino para responder aos potenciais riscos ambientais, como por exemplo: incêndio, proliferação descontrolada/desequilíbrio de espécies nativas ou não da fauna e contaminação de águas pluviais (FALCÃO, 2010).

O segundo critério a ser analisado é "gestão dos resíduos sólidos", o qual analisará como se dá o processo de coleta e destinação do lixo em um destino turístico, visto que, o lixo representa um dos principais problemas discutidos pelos gestores públicos (FALCÃO, 2010).

Sobre o critério "gestão de energia", pode-se afirmar que buscará avaliar principalmente, a natureza do tipo de energia predominantemente produzida no destino turístico, se esta é renovável ou não (FALCÃO, 2010).

Além disso, a autora supracitada destaca que o critério "Conservação e gestão do uso da água" avaliará o acesso da população aos serviços de água tratada e existência ou não de colapsos durante os períodos de visitação. Já o critério "Saneamento básico" consiste analisar o saneamento de um destino turístico e como é o tratamento de esgoto como um todo.

Logo, cada critério de análise das dimensões deve ser posicionado em uma escala que apresenta quatro níveis: inexistente, fraco, moderado e forte, e cada nível (Quadro 5) possui um peso (FALCÃO, 2010). De acordo com o posicionamento dos critérios de análise dessa dimensão nos níveis indicados no Quadro 5, tem-se uma pontuação final. 
Quadro 4: Matriz de parâmetros para indicador gestão do meio ambiente.

Table 4: Matrix parameters for environmental management indicator.

\begin{tabular}{|c|c|c|c|c|}
\hline \multicolumn{5}{|c|}{ GESTÃO DO MEIO AMBIENTE } \\
\hline \multirow[t]{2}{*}{ Parâmetros } & \multicolumn{4}{|c|}{ Pesos } \\
\hline & Inexistente & Fraco & Moderado & Forte \\
\hline $\begin{array}{l}\text { Preparação } \\
\text { às } \\
\text { emergências } \\
\text { ambientais }\end{array}$ & $\begin{array}{c}\text { Ausência de } \\
\text { preparação } \\
\text { as } \\
\text { emergências } \\
\text { ambientais }\end{array}$ & $\begin{array}{l}\text { Reconhece a } \\
\text { relevância de } \\
\text { estar prepara- } \\
\text { do para emer- } \\
\text { gências am- } \\
\text { bientais, mas } \\
\text { não possui pro- } \\
\text { cedimentos de } \\
\text { ação para tais } \\
\text { emergências }\end{array}$ & $\begin{array}{l}\text { Conhece os } \\
\text { riscos } \\
\text { ambientais e } \\
\text { possui } \\
\text { procedimentos } \\
\text { padrões, mas } \\
\text { estes nunca } \\
\text { foram testados }\end{array}$ & $\begin{array}{l}\text { Conhece os riscos } \\
\text { ambientais, além da } \\
\text { elaboração e testes de } \\
\text { procedimentos de } \\
\text { ação mediante } \\
\text { ocorrência de alguma } \\
\text { emergência }\end{array}$ \\
\hline $\begin{array}{l}\text { Gestão dos } \\
\text { resíduos } \\
\text { sólidos }\end{array}$ & $\begin{array}{l}\text { Inexistência } \\
\text { de coleta } \\
\text { pública dos } \\
\text { resíduos } \\
\text { sólidos }\end{array}$ & $\begin{array}{l}\text { Possui coleta } \\
\text { pública dos } \\
\text { resíduos } \\
\text { sólidos, mas a } \\
\text { destinação } \\
\text { destes não é } \\
\text { adequada }\end{array}$ & $\begin{array}{l}\text { Possui coleta } \\
\text { seletiva dos } \\
\text { resíduos sólidos } \\
\text { e sua } \\
\text { destinação é } \\
\text { adequada }\end{array}$ & $\begin{array}{l}\text { Possui coleta seletiva } \\
\text { e destinação } \\
\text { adequada dos } \\
\text { resíduos sólidos, } \\
\text { resíduos orgânicos são } \\
\text { reutilizados além de } \\
\text { campanhas educativas } \\
\text { e fóruns participativos } \\
\text { sobre o problema do } \\
\text { lixo no destino }\end{array}$ \\
\hline $\begin{array}{c}\text { Gestão de } \\
\text { energia }\end{array}$ & $\begin{array}{l}\text { Não há } \\
\text { utilização de } \\
\text { fontes de } \\
\text { energia } \\
\text { renováveis }\end{array}$ & $\begin{array}{c}\text { Há } \\
\text { predominância } \\
\text { de utilização de } \\
\text { fontes não } \\
\text { renováveis, } \\
\text { energia uma } \\
\text { vez que a } \\
\text { utilização de } \\
\text { fontes } \\
\text { renováveis não } \\
\text { é significativa } \\
\end{array}$ & $\begin{array}{l}\text { Há utilização } \\
\text { significativa de } \\
\text { fontes de } \\
\text { energia } \\
\text { renováveis } \\
\text { devido às } \\
\text { condições } \\
\text { geográficas do } \\
\text { destino, porém } \\
\text { não são } \\
\text { predominantes }\end{array}$ & $\begin{array}{l}\text { Há a predominância de } \\
\text { fontes renováveis de } \\
\text { energia além de } \\
\text { campanhas de } \\
\text { incentivos aos } \\
\text { visitantes a } \\
\text { racionalizar o uso de } \\
\text { energia elétrica }\end{array}$ \\
\hline $\begin{array}{l}\text { Conservação } \\
\text { e gestão do } \\
\text { uso da água }\end{array}$ & $\begin{array}{l}\text { Não há } \\
\text { ações e } \\
\text { planejamento } \\
\text { para gestão } \\
\text { do uso da } \\
\text { água }\end{array}$ & $\begin{array}{c}\text { Há colapsos } \\
\text { frequentes na } \\
\text { distribuição de } \\
\text { água }\end{array}$ & $\begin{array}{l}\text { Há colapsos na } \\
\text { distribuição de } \\
\text { água no destino } \\
\text { durante o } \\
\text { período de alta } \\
\text { estação }\end{array}$ & $\begin{array}{c}\text { A gestão consegue } \\
\text { mitigar os colapsos de } \\
\text { água na alta estação, } \\
\text { além de realizar } \\
\text { eventos e ações } \\
\text { promovendo o } \\
\text { consumo consciente } \\
\text { da água }\end{array}$ \\
\hline $\begin{array}{c}\text { Saneamento } \\
\text { básico }\end{array}$ & $\begin{array}{c}\text { Não há } \\
\text { saneamento } \\
\text { básico no } \\
\text { destino } \\
\text { turístico }\end{array}$ & $\begin{array}{l}\text { O saneamento } \\
\text { básico } \\
\text { compreende } \\
\text { pequena } \\
\text { parcela da } \\
\text { população }\end{array}$ & $\begin{array}{l}\text { O saneamento } \\
\text { básico } \\
\text { compreende } \\
\text { toda a } \\
\text { população, mas } \\
\text { apresenta } \\
\text { tratamento } \\
\text { inadequado }\end{array}$ & $\begin{array}{l}\text { O saneamento básico } \\
\text { é um aspecto frequen- } \\
\text { temente planejado } \\
\text { pela gestão do destino } \\
\text { conseguindo suprir a } \\
\text { população mesmo com } \\
\text { aumento da densidade } \\
\text { demográfica e destina- } \\
\text { do adequadamente os } \\
\text { efluentes. }\end{array}$ \\
\hline
\end{tabular}

Fonte: Adaptado de Falcão (2010).

Source: Adapted from Falcão (2010). 
Quadro 5: Relação entre níveis e pesos da matriz de parâmetro.

Table 5: Relationship between levels and weights of the parameter array.

\begin{tabular}{|c|c|}
\hline Níveis da Avaliação & Pesos \\
\hline Inexistente & 0 \\
\hline Fraco & 1 \\
\hline Moderado & 2 \\
\hline Forte & 3 \\
\hline
\end{tabular}

Fonte: Adaptado de Falcão (2010).

Source: Adapted from Falcão (2010).

Assim, a fim de avaliar os resultados da dimensão será estabelecido que se a dimensão apresentar de 0 a $25 \%$ dos pontos expressará um resultado insatisfatório; de 26 a 50\% será entendido como uma situação pouca satisfatória; de 51 a $75 \%$ moderadamente satisfatório e de 76 a 100\% satisfatório (FALCÃO, 2010).

Tais dimensões foram analisadas de acordo com os critérios expostos acima. Em seguida o resultado dessa avaliação e porcentagem ficam posicionados em uma régua destinada para a dimensão analisada, para que se possa ter uma visão de como se encontra essa dimensão no universo determinado dessa referida pesquisa. A figura 2 mostra a ilustração da régua que será gerada no final.

Figura 2: Régua referente à porcentagem gerada na análise da dimensão ambiental da sustentabilidade proposto por Falcão (2010).

Figure 2: Rule regarding the percentage generated in the analysis of the environmental dimension of sustainability proposed by Falcão (2010).

Ambiental

\section{Análise da dimensão ambiental da sustentabilidade dos geossítios do Projeto Geoparque Seridó baseado no modelo de Falcão (2010)}

\section{Educação Ambiental}

Buscou-se analisar a primeira dimensão Educação Ambiental, observando o primeiro critério que é o Acesso da Comunidade à Educação Ambiental nos geossítios, em que se constatou que existem ações esporádicas realizadas juntamente com as escolas, por meio de palestras ressaltando a importância do local para a sua comunidade, como deixa claro os entrevistados "O processo de educação ambiental voltada aos geossítios é feito nas escolas, principalmente nas séries mais baixas, onde nosso foco é trabalhar mais com palestras que os próprios professores inserem no ano letivo". Assim seu aspecto foi considerado Moderado nos geossítios Serra Verde, Pico Totoró, Açude Gargalheiras, Cruzeiro de Acari e Xiquexique (Quadro 6), pois as ações realizadas nas escolas, buscando a interação desses alunos com o lugar representam ações voltadas ao meio ambiente na comunidade. 
Quadro 6: Resultados obtidos para o indicador Educação Ambiental - Acesso da Comunidade à Educação Ambiental.

Table 6: Results for the Environmental Education indicator - Community Access to Environmental Education.

\begin{tabular}{|c|c|c|c|c|}
\hline \multicolumn{5}{|c|}{$\begin{array}{c}\text { EDUCAÇÃO AMBIENTAL } \\
\text { Acesso da Comunidade à Educação Ambiental }\end{array}$} \\
\hline \multirow[b]{2}{*}{ Geossítios } & \multicolumn{4}{|c|}{ Pesos } \\
\hline & $\begin{array}{c}\text { Inexistente } \\
(0)\end{array}$ & $\begin{array}{c}\text { Fraco } \\
(1)\end{array}$ & $\begin{array}{c}\text { Moderado } \\
(2)\end{array}$ & $\begin{array}{c}\text { Forte } \\
\text { (3) }\end{array}$ \\
\hline $\begin{array}{l}\text { Cânions dos } \\
\text { Apertados, } \\
\text { Poço do Arroz, } \\
\text { Marmitas do } \\
\text { Rio Carnaúba }\end{array}$ & $\begin{array}{c}\text { Não há eventos } \\
\text { disponíveis para a } \\
\text { comunidade que } \\
\text { abordem a } \\
\text { questão } \\
\text { ambiental nem há } \\
\text { a participação das } \\
\text { escolas na causa }\end{array}$ & $\begin{array}{c}\text { Há eventos } \\
\text { esporádicos } \\
\text { sobre o meio } \\
\text { ambiente, mas } \\
\text { não há } \\
\text { articulação das } \\
\text { escolas para } \\
\text { exercer um } \\
\text { trabalho } \\
\text { paralelo }\end{array}$ & $\begin{array}{l}\text { Há eventos } \\
\text { esporádicos } \\
\text { sobre o } \\
\text { meio } \\
\text { ambiente e } \\
\text { as escolas } \\
\text { participam }\end{array}$ & $\begin{array}{l}\text { Há eventos gratuitos } \\
\text { regularmente que } \\
\text { tratam de assuntos } \\
\text { relacionados ao } \\
\text { meio ambiente do } \\
\text { local, além da } \\
\text { articulação e } \\
\text { participação das } \\
\text { escolas nesses } \\
\text { eventos }\end{array}$ \\
\hline \multirow[b]{2}{*}{ Geossítios } & \multicolumn{4}{|c|}{ Pesos } \\
\hline & $\begin{array}{l}\text { Inexistente } \\
(0)\end{array}$ & $\begin{array}{c}\text { Fraco } \\
(1)\end{array}$ & $\begin{array}{c}\text { Moderado } \\
(2)\end{array}$ & $\begin{array}{l}\text { Forte } \\
(3)\end{array}$ \\
\hline $\begin{array}{c}\text { Cruzeiro de } \\
\text { Cerro Corá, } \\
\text { Vale } \\
\text { Vulcânico, } \\
\text { Mirante Santa } \\
\text { Rita, Morro do } \\
\text { Cruzeiro, } \\
\text { Açude } \\
\text { Boqueirão, } \\
\text { Mirador, } \\
\text { Monte do Galo }\end{array}$ & $\begin{array}{l}\text { Não há eventos } \\
\text { disponíveis para a } \\
\text { comunidade que } \\
\text { abordem a } \\
\text { questão } \\
\text { ambiental nem há } \\
\text { a participação das } \\
\text { escolas na causa }\end{array}$ & $\begin{array}{c}\text { Há eventos } \\
\text { esporádicos } \\
\text { sobre o meio } \\
\text { ambiente, mas } \\
\text { não há } \\
\text { articulação das } \\
\text { escolas para } \\
\text { exercer um } \\
\text { trabalho } \\
\text { paralelo }\end{array}$ & $\begin{array}{l}\text { Há eventos } \\
\text { esporádicos } \\
\text { sobre o } \\
\text { meio } \\
\text { ambiente e } \\
\text { as escolas } \\
\text { participam }\end{array}$ & $\begin{array}{l}\text { Há eventos gratuitos } \\
\text { regularmente que } \\
\text { tratam de assuntos } \\
\text { relacionados ao } \\
\text { meio ambiente do } \\
\text { local, além da } \\
\text { articulação e } \\
\text { participação das } \\
\text { escolas nesses } \\
\text { eventos }\end{array}$ \\
\hline \multirow[b]{2}{*}{ Geossítios } & \multicolumn{4}{|c|}{ Pesos } \\
\hline & $\begin{array}{c}\text { Inexistente } \\
(0)\end{array}$ & $\begin{array}{c}\text { Fraco } \\
(1)\end{array}$ & $\begin{array}{l}\text { Moderado } \\
\text { (2) }\end{array}$ & $\begin{array}{c}\text { Forte } \\
\text { (3) }\end{array}$ \\
\hline $\begin{array}{l}\text { Serra Verde, } \\
\text { Pico Totoró, } \\
\text { Açude } \\
\text { Gargalheiras, } \\
\text { Cruzeiro de } \\
\text { Acari e } \\
\text { Xiquexique }\end{array}$ & $\begin{array}{c}\text { Não há eventos } \\
\text { disponíveis para a } \\
\text { comunidade que } \\
\text { abordem a } \\
\text { questão } \\
\text { ambiental nem há } \\
\text { a participação das } \\
\text { escolas na causa }\end{array}$ & $\begin{array}{c}\text { Há eventos } \\
\text { esporádicos } \\
\text { sobre o meio } \\
\text { ambiente, mas } \\
\text { não há articula- } \\
\text { ção das escolas } \\
\text { para exercer um } \\
\text { trabalho } \\
\text { paralelo } \\
\end{array}$ & $\begin{array}{l}\text { Há eventos } \\
\text { esporádicos } \\
\text { sobre o } \\
\text { meio } \\
\text { ambiente e } \\
\text { as escolas } \\
\text { participam }\end{array}$ & $\begin{array}{l}\text { Há eventos gratuitos } \\
\text { regularmente que } \\
\text { tratam de assuntos } \\
\text { relacionados ao } \\
\text { meio ambiente do lo- } \\
\text { cal, além da articu- } \\
\text { lação e participação } \\
\text { das escolas nesses } \\
\text { eventos }\end{array}$ \\
\hline \multirow[b]{2}{*}{ Geossítio } & \multicolumn{4}{|c|}{ Pesos } \\
\hline & $\begin{array}{c}\text { Inexistente } \\
(0)\end{array}$ & $\begin{array}{c}\text { Fraco } \\
(1)\end{array}$ & $\begin{array}{l}\text { Moderado } \\
\text { (2) }\end{array}$ & $\begin{array}{c}\text { Forte } \\
(3)\end{array}$ \\
\hline Mina Brejuí & $\begin{array}{l}\text { Não há eventos } \\
\text { disponíveis para a } \\
\text { comunidade que } \\
\text { abordem a } \\
\text { questão } \\
\text { ambiental nem há } \\
\text { a participação das } \\
\text { escolas na causa }\end{array}$ & $\begin{array}{l}\text { Há eventos } \\
\text { esporádicos so- } \\
\text { bre o meio am- } \\
\text { biente, mas não } \\
\text { há articulação } \\
\text { das escolas } \\
\text { para exercer um } \\
\text { trabalho } \\
\text { paralelo }\end{array}$ & $\begin{array}{l}\text { Há eventos } \\
\text { esporádicos } \\
\text { sobre o } \\
\text { meio } \\
\text { ambiente e } \\
\text { as escolas } \\
\text { participam }\end{array}$ & $\begin{array}{l}\text { Há eventos gratuitos } \\
\text { regularmente que } \\
\text { tratam de assuntos } \\
\text { relacionados ao } \\
\text { meio ambiente do } \\
\text { local, além da articu- } \\
\text { lação e participação } \\
\text { das escolas nesses } \\
\text { eventos }\end{array}$ \\
\hline
\end{tabular}


Os geossítios Cruzeiro de Cerro Corá, Vale Vulcânico, Mirante Santa Rita, Morro do Cruzeiro, Açude Boqueirão, Mirador, Monte do Galo tiveram desempenho Fraco (Quadro 6), que segundo um entrevistado "tentamos levar por meio de palestras nas escolas ações que busquem a sensibilização dos alunos para que divulguem aos seus pais, mas vemos que esse conhecimento deles fica apenas em sala de aula". Já o geossítio Mina Brejuí obteve aspecto Forte (Quadro 6), onde um entrevistado explica que "aqui na Mina Brejuí procuramos realizar atividades que visam a resguardar o meio ambiente juntamente com os alunos e a nossa comunidade através do ensino ao reaproveitamento do espaço para uma melhor convivência".

Os demais geossítios Cânions dos Apertados, Poço do Arroz, Marmitas do Rio Carnaúba tiveram resultados Inexistente (Quadro 6), devido à ausência de ações voltadas a população do entorno dos geossítios. O que se percebe são algumas atividades esporádicas por parte de alunos da UFRN, mas que são em formas de visitação ao lugar para pesquisas.

O segundo critério de análise dessa dimensão é a Valorização do Patrimônio Ambiental, onde foi evidenciado que há uma consciência na comunidade da importância do local, mas ressalta que a falta de investimentos dificulta uma melhor aproximação da comunidade com o local, pois "numa secretaria que é juntamente com a de agricultura, turismo e meio ambiente, torna-se uma secretaria escassa de recursos, então tudo tem um impacto, dificulta qualquer ação". Com isso, o nível de valorização do patrimônio ambiental foi considerado Moderado (Quadro 7) nos geossítios Serra Verde, Mirante Santa Rita, Açude Gargalheiras, Cruzeiro de Acari e Mirador.

No geossítio Mina Brejuí alcançou o nível Forte (Quadro 7), pois um dos entrevistados expôs que "temos aqui na Mina Brejuí eventos que acontecem regularmente, como é o caso da Semana de Esportes e Cultura que é realizado no mês de setembro e visa além da realização de práticas esportivas, ações educativas que buscam estimular a consciência ambiental. Além disso, existem dois projetos realizados nas escolas: o projeto atrelado a Campanha da Fraternidade - Fraternidade e a vida no planeta, que busca conscientizar a comunidade para a preservação da natureza; e o projeto a vida na caatinga, desenvolvido devido à preocupação das escolas e da comunidade com as queimadas realizadas nas proximidades". Vale ressaltar que, tais projetos objetivam conscientizar os alunos e a comunidade por meio da educação ambiental para a proteção do meio ambiente como um todo.

Já os geossítios Cruzeiro de Cerro Corá, Vale Vulcânico, Pico Totoró, Morro do Cruzeiro, Cruzeiro de Acari, Poço do Arroz, Marmitas Rio Carnaúba, Açude Boqueirão, Monte do Galo obtiveram nível Fraco (Quadro 7), onde os entrevistados expuseram "a falta de consciência da comunidade sobre o potencial turístico que o local possui torna-se o principal problema para o seu desenvolvimento turístico". 
Quadro 7: Resultados obtidos para o indicador Educação Ambiental - Valorização do Patrimônio Ambiental.

Table 7: Results for the Environmental Education indicator - Environmental Heritage Enhancement.

\begin{tabular}{|c|c|c|c|c|}
\hline \multicolumn{5}{|c|}{$\begin{array}{c}\text { EDUCAÇÃO AMBIENTAL } \\
\text { Valorização do Patrimônio Ambiental }\end{array}$} \\
\hline \multirow[b]{2}{*}{ Geossítios } & \multicolumn{4}{|c|}{ Pesos } \\
\hline & $\begin{array}{c}\text { Inexistente } \\
(0)\end{array}$ & $\begin{array}{l}\text { Fraco } \\
\text { (1) }\end{array}$ & $\begin{array}{l}\text { Moderado } \\
(2)\end{array}$ & $\begin{array}{l}\text { Forte } \\
\text { (3) }\end{array}$ \\
\hline $\begin{array}{c}\text { Cruzeiro de } \\
\text { Cerro Corá, } \\
\text { Vale Vulcânico, } \\
\text { Pico Totoró, } \\
\text { Morro do } \\
\text { Cruzeiro, } \\
\text { Cruzeiro de } \\
\text { Acari, Poço do } \\
\text { Arroz, Marmitas } \\
\text { Rio Carnaúba, } \\
\text { Açude } \\
\text { Boqueirão, } \\
\text { Monte do Galo }\end{array}$ & $\begin{array}{c}\text { Não há } \\
\text { eventos } \\
\text { disponíveis } \\
\text { para a } \\
\text { comunidade } \\
\text { que abordem a } \\
\text { questão } \\
\text { ambiental nem } \\
\text { há a } \\
\text { participação } \\
\text { das escolas na } \\
\text { causa } \\
\end{array}$ & $\begin{array}{c}\text { Há eventos } \\
\text { esporádicos } \\
\text { sobre o meio } \\
\text { ambiente, mas } \\
\text { não há } \\
\text { articulação } \\
\text { das escolas } \\
\text { para exercer } \\
\text { um trabalho } \\
\text { paralelo }\end{array}$ & $\begin{array}{c}\text { Há eventos } \\
\text { esporádicos } \\
\text { sobre o meio } \\
\text { ambiente e as } \\
\text { escolas } \\
\text { participam }\end{array}$ & $\begin{array}{l}\text { Há eventos } \\
\text { gratuitos } \\
\text { regularmente que } \\
\text { tratam de } \\
\text { assuntos } \\
\text { relacionados ao } \\
\text { meio ambiente do } \\
\text { local, além da } \\
\text { articulação e } \\
\text { participação das } \\
\text { escolas nesses } \\
\text { eventos }\end{array}$ \\
\hline \multirow[b]{2}{*}{ Geossítios } & \multicolumn{4}{|c|}{ Pesos } \\
\hline & $\begin{array}{l}\text { Inexistente } \\
(0)\end{array}$ & $\begin{array}{c}\text { Fraco } \\
\text { (1) }\end{array}$ & $\begin{array}{l}\text { Moderado } \\
\text { (2) }\end{array}$ & $\begin{array}{l}\text { Forte } \\
\text { (3) }\end{array}$ \\
\hline $\begin{array}{l}\text { Serra Verde, } \\
\text { Mirante Santa } \\
\text { Rita, Açude } \\
\text { Gargalheiras, } \\
\text { Cruzeiro de } \\
\text { Acari e Mirador }\end{array}$ & $\begin{array}{c}\text { Não há } \\
\text { eventos } \\
\text { disponíveis } \\
\text { para a } \\
\text { comunidade } \\
\text { que abordem a } \\
\text { questão } \\
\text { ambiental nem } \\
\text { há a } \\
\text { participação } \\
\text { das escolas na } \\
\text { causa } \\
\end{array}$ & $\begin{array}{c}\text { Há eventos } \\
\text { esporádicos } \\
\text { sobre o meio } \\
\text { ambiente, mas } \\
\text { não há } \\
\text { articulação } \\
\text { das escolas } \\
\text { para exercer } \\
\text { um trabalho } \\
\text { paralelo }\end{array}$ & $\begin{array}{c}\text { Há eventos } \\
\text { esporádicos } \\
\text { sobre o meio } \\
\text { ambiente e as } \\
\text { escolas } \\
\text { participam }\end{array}$ & $\begin{array}{l}\text { Há eventos } \\
\text { gratuitos } \\
\text { regularmente que } \\
\text { tratam de } \\
\text { assuntos } \\
\text { relacionados ao } \\
\text { meio ambiente do } \\
\text { local, além da } \\
\text { articulação e } \\
\text { participação das } \\
\text { escolas nesses } \\
\text { eventos }\end{array}$ \\
\hline \multirow[b]{2}{*}{ Geossítios } & \multicolumn{4}{|c|}{ Pesos } \\
\hline & $\begin{array}{c}\text { Inexistente } \\
(0)\end{array}$ & $\begin{array}{c}\text { Fraco } \\
(1)\end{array}$ & $\begin{array}{c}\text { Moderado } \\
(2)\end{array}$ & $\begin{array}{l}\text { Forte } \\
\text { (3) }\end{array}$ \\
\hline Mina Brejuí & $\begin{array}{c}\text { Não há } \\
\text { eventos } \\
\text { disponíveis } \\
\text { para a } \\
\text { comunidade } \\
\text { que abordem a } \\
\text { questão } \\
\text { ambiental nem } \\
\text { há a } \\
\text { participação } \\
\text { das escolas na } \\
\text { causa }\end{array}$ & $\begin{array}{c}\text { Há eventos } \\
\text { esporádicos } \\
\text { sobre o meio } \\
\text { ambiente, mas } \\
\text { não há } \\
\text { articulação } \\
\text { das escolas } \\
\text { para exercer } \\
\text { um trabalho } \\
\text { paralelo }\end{array}$ & $\begin{array}{c}\text { Há eventos } \\
\text { esporádicos } \\
\text { sobre o meio } \\
\text { ambiente e as } \\
\text { escolas } \\
\text { participam }\end{array}$ & $\begin{array}{l}\text { Há eventos } \\
\text { gratuitos } \\
\text { regularmente que } \\
\text { tratam de } \\
\text { assuntos } \\
\text { relacionados ao } \\
\text { meio ambiente do } \\
\text { local, além da } \\
\text { articulação e } \\
\text { participação das } \\
\text { escolas nesses } \\
\text { eventos }\end{array}$ \\
\hline
\end{tabular}




\section{Conservação e Proteção do Produto Turístico}

Sobre a dimensão Conservação e Proteção do Produto Turístico foram analisados os critérios a seguir:

Identificou-se por meio do critério Preservação dos Recursos Naturais que nos geossítios Serra Verde, Cruzeiro de Cerro Corá Pico Totoró, Morro do Cruzeiro, Cânion dos Apertados, Poço do Arroz, Marmitas do Rio Carnaúba não há fiscalização voltada a sua conservação prejudicando o trabalho dos condutores locais, conforme relatam os entrevistados "a situação dos geossítios é boa, mas temos a degradação da arte rupestre, um pouco de lixo deixado devido ser mais acessível que os demais locais, e assim facilita o fazer de fogo, como também, a caça precária”. Por isso, considerou-se nível Inexistente (Quadro 8, próxima página). Nos geossítios Vale Vulcânico, Açude Gargalheiras, Açude Boqueirão, Xiquexique se alcançou nível Moderado (Quadro 8, próxima página), onde de acordo com os entrevistados "esses geossítio são os que menos sofrem agressão, por causa do seu acesso, pois poucas pessoas vão ao local, apenas levamos os grupos, e como são grupos de estudos há uma maior preocupação na sua conservação, e quanto aos açudes encontram-se ambientalmente bem conservado, isso devido estar inserido em área da União, onde não é permitido sem autorização do DNOCS".

Para os geossítios Mirante Santa Rita, Mirador, Monte do Galo tiveram nível Fraco, pois de acordo com, alguns entrevistados "a questão da legislação é de acordo com a do Estado, não existe a do município, é decretado pela lei estadual, e essa fiscalização é por conta do IDEMA e IBAMA. E como o município necessita de investimentos, busca-se está sempre aberto aos advindos vindo dos proprietários dos residenciais".

Apenas o geossítio Mina Brejuí obteve o nível Forte (Quadro 8, próxima página), pois segundo um entrevistado "a mineração possui fiscalização intensa no cumprimento da legislação ambiental dos órgãos competentes a fim de sanar problemas quanto à questão das áreas naturais".

No critério Poluição Visual e Poluição Sonora não foi diagnosticado algo que atrapalhasse a vista dos atrativos pertencentes aos geossítios Serra Verde, Vale Vulcânico, Mirante Santa Rita, Pico Totoró, Mina Brejuí, Açude Gargalheiras, Cruzeiro de Acari, Poço do Arroz, Marmitas do Rio Carnaúba, Mirador, Xiquexique e com isso o nível considerado foi o Forte (Quadro 9). Já os geossítios Cruzeiro de Cerro Corá, Morro do Cruzeiro, Açude Boqueirão obtiveram nível Moderado (Quadro 9), pois as pocilgas relatadas no quesito anterior comprometem a imagem do local, e com isso, a sua visitação. E os demais geossítios Cânion dos Apertados e Monte do Galo o nível foi Fraco (Quadro 9), pois perceberam que os fluxos de visitantes comprometem o visual do lugar com a sujeira/lixo deixado e pichações feitas no local, assim como, os sons ligados em seus carros. 
Quadro 8: Resultados obtidos para o indicador Conservação e Proteção do Produto Turístico - Preservação do Produto Turístico.

Table 8: Results obtained for the indicator Conservation and Tourism Product Protection Preservation of Tourism Product.

\begin{tabular}{|c|c|c|c|c|}
\hline \multicolumn{5}{|c|}{$\begin{array}{c}\text { CONSERVAÇÃO E PROTEÇÃO DO PRODUTO TURÍSTICO } \\
\text { Preservação do Produto Turístico }\end{array}$} \\
\hline \multirow[b]{2}{*}{ Geossítios } & \multicolumn{4}{|c|}{ Pesos } \\
\hline & $\begin{array}{c}\text { Inexistente } \\
(0)\end{array}$ & $\begin{array}{c}\text { Fraco } \\
(1)\end{array}$ & $\begin{array}{c}\text { Moderado } \\
(2)\end{array}$ & $\begin{array}{c}\text { Forte } \\
(3)\end{array}$ \\
\hline $\begin{array}{c}\text { Serra Verde, } \\
\text { Cruzeiro de } \\
\text { Cerro Corá Pico } \\
\text { Totoró, Morro } \\
\text { do Cruzeiro, } \\
\text { Cânion dos } \\
\text { Apertados, Poço } \\
\text { do Arroz, } \\
\text { Marmitas do Rio } \\
\text { Carnaúba }\end{array}$ & $\begin{array}{c}\text { Não há eventos } \\
\text { disponíveis para } \\
\text { a comunidade } \\
\text { que abordem a } \\
\text { questão } \\
\text { ambiental nem } \\
\text { há a } \\
\text { participação das } \\
\text { escolas na } \\
\text { causa }\end{array}$ & $\begin{array}{l}\text { Há eventos } \\
\text { esporádicos } \\
\text { sobre o meio } \\
\text { ambiente, mas } \\
\text { não há } \\
\text { articulação das } \\
\text { escolas para } \\
\text { exercer um } \\
\text { trabalho } \\
\text { paralelo }\end{array}$ & $\begin{array}{l}\text { Há eventos } \\
\text { esporádicos } \\
\text { sobre o } \\
\text { meio } \\
\text { ambiente e } \\
\text { as escolas } \\
\text { participam }\end{array}$ & $\begin{array}{c}\text { Há eventos } \\
\text { gratuitos } \\
\text { regularmente que } \\
\text { tratam de assuntos } \\
\text { relacionados ao } \\
\text { meio ambiente do } \\
\text { local, além da } \\
\text { articulação e } \\
\text { participação das } \\
\text { escolas nesses } \\
\text { eventos }\end{array}$ \\
\hline \multirow[b]{2}{*}{ Geossítios } & \multicolumn{4}{|c|}{ Pesos } \\
\hline & $\begin{array}{l}\text { Inexistente } \\
(0)\end{array}$ & $\begin{array}{l}\text { Fraco } \\
(1)\end{array}$ & $\begin{array}{l}\text { Moderado } \\
\text { (2) }\end{array}$ & $\begin{array}{l}\text { Forte } \\
(3)\end{array}$ \\
\hline $\begin{array}{l}\text { Mirante Santa } \\
\text { Rita, Mirador, } \\
\text { Monte do Galo }\end{array}$ & $\begin{array}{c}\text { Não há eventos } \\
\text { disponíveis para } \\
\text { a comunidade } \\
\text { que abordem a } \\
\text { questão } \\
\text { ambiental nem } \\
\text { há a } \\
\text { participação das } \\
\text { escolas na } \\
\text { causa }\end{array}$ & $\begin{array}{l}\text { Há eventos } \\
\text { esporádicos } \\
\text { sobre o meio } \\
\text { ambiente, mas } \\
\text { não há } \\
\text { articulação das } \\
\text { escolas para } \\
\text { exercer um } \\
\text { trabalho } \\
\text { paralelo }\end{array}$ & $\begin{array}{l}\text { Há eventos } \\
\text { esporádicos } \\
\text { sobre o } \\
\text { meio } \\
\text { ambiente e } \\
\text { as escolas } \\
\text { participam }\end{array}$ & $\begin{array}{c}\text { Há eventos } \\
\text { gratuitos regular- } \\
\text { mente que tratam } \\
\text { de assuntos relacio- } \\
\text { nados ao meio } \\
\text { ambiente do local, } \\
\text { além da articulação } \\
\text { e participação das } \\
\text { escolas nesses } \\
\text { eventos }\end{array}$ \\
\hline & \multicolumn{4}{|c|}{ Pesos } \\
\hline Geossítios & $\begin{array}{c}\text { Inexistente } \\
(0)\end{array}$ & $\begin{array}{l}\text { Fraco } \\
(1)\end{array}$ & $\begin{array}{l}\text { Moderado } \\
\text { (2) }\end{array}$ & $\begin{array}{c}\text { Forte } \\
\text { (3) }\end{array}$ \\
\hline $\begin{array}{l}\text { Vale Vulcânico, } \\
\text { Açude } \\
\text { Gargalheiras, } \\
\text { Açude } \\
\text { Boqueirão, } \\
\text { Xiquexique }\end{array}$ & $\begin{array}{c}\text { Não há eventos } \\
\text { disponíveis para } \\
\text { a comunidade } \\
\text { que abordem a } \\
\text { questão } \\
\text { ambiental nem } \\
\text { há a } \\
\text { participação das } \\
\text { escolas na } \\
\text { causa }\end{array}$ & $\begin{array}{l}\text { Há eventos } \\
\text { esporádicos } \\
\text { sobre o meio } \\
\text { ambiente, mas } \\
\text { não há } \\
\text { articulação das } \\
\text { escolas para } \\
\text { exercer um } \\
\text { trabalho } \\
\text { paralelo }\end{array}$ & $\begin{array}{l}\text { Há eventos } \\
\text { esporádicos } \\
\text { sobre o } \\
\text { meio } \\
\text { ambiente e } \\
\text { as escolas } \\
\text { participam }\end{array}$ & $\begin{array}{c}\text { Há eventos } \\
\text { gratuitos regular- } \\
\text { mente que tratam } \\
\text { de assuntos relacio- } \\
\text { nados ao meio } \\
\text { ambiente do local, } \\
\text { além da articulação } \\
\text { e participação das } \\
\text { escolas nesses } \\
\text { eventos }\end{array}$ \\
\hline \multirow[b]{2}{*}{ Geossítios } & \multicolumn{4}{|c|}{ Pesos } \\
\hline & $\begin{array}{c}\text { Inexistente } \\
(0)\end{array}$ & $\begin{array}{l}\text { Fraco } \\
\text { (1) }\end{array}$ & $\begin{array}{l}\text { Moderado } \\
\text { (2) }\end{array}$ & $\begin{array}{l}\text { Forte } \\
\text { (3) }\end{array}$ \\
\hline Mina Brejuí & $\begin{array}{c}\text { Não há eventos } \\
\text { disponíveis para } \\
\text { a comunidade } \\
\text { que abordem a } \\
\text { questão am- } \\
\text { biental nem há } \\
\text { a participação } \\
\text { das escolas na } \\
\text { causa }\end{array}$ & $\begin{array}{l}\text { Há eventos es- } \\
\text { porádicos sobre } \\
\text { o meio ambien- } \\
\text { te, mas não há } \\
\text { articulação das } \\
\text { escolas para } \\
\text { exercer um tra- } \\
\text { balho paralelo }\end{array}$ & $\begin{array}{l}\text { Há eventos } \\
\text { esporádicos } \\
\text { sobre o } \\
\text { meio } \\
\text { ambiente e } \\
\text { as escolas } \\
\text { participam }\end{array}$ & $\begin{array}{l}\text { Há eventos gratui- } \\
\text { tos regularmente } \\
\text { que tratam de as- } \\
\text { suntos relacionados } \\
\text { ao meio ambiente } \\
\text { do local, além da } \\
\text { articulação e partici- } \\
\text { pação das escolas } \\
\text { nesses eventos }\end{array}$ \\
\hline
\end{tabular}


Quadro 9: Resultados obtidos para o indicador Conservação e Proteção do Produto Turístico - Poluição Visual e Poluição Sonora.

Table 9: Results for the indicator Conservation and Tourism Product Protection - Visual Pollution and Noise Pollution.

\begin{tabular}{|c|c|c|c|c|}
\hline \multicolumn{5}{|c|}{ CONSERVAÇÃO E PROTEÇÃO DO PRODUTO TURÍSTICO } \\
Poluição Visual e Poluição Sonora
\end{tabular}




\section{Gestão do Meio Ambiente}

Para a dimensão ambiental Gestão do Meio Ambiente tem-se:

O critério Preparação às Emergências Ambientais obteve o nível Fraco em quase todos os geossítios (Quadro 10), pois segundo os entrevistados "há a consciência de que se deve estar preparado para os eventuais problemas". Desse modo, o único geossítio que recebeu nível Forte (Quadro 10) foi Mina Brejuí, porque segundo um entrevistado "Temos um plano emergencial para eventuais acontecimentos. Como também elaboramos testes desses procedimentos para que assim estejamos preparados sempre".

Quadro 10: Resultados obtidos para o indicador Gestão do Meio Ambiente - Preparação às Emergências Ambientais.

Table 10: Results for the management indicator of the Environment - Preparing the Environmental Emergencies.

\begin{tabular}{|c|c|c|c|c|}
\hline \multicolumn{5}{|c|}{$\begin{array}{c}\text { GESTÃO DO MEIO AMBIENTE } \\
\text { Preparação às Emergências Ambientais }\end{array}$} \\
\hline \multirow[b]{2}{*}{ Geossítios } & \multicolumn{4}{|c|}{ Pesos } \\
\hline & $\begin{array}{c}\text { Inexistente } \\
\text { (0) }\end{array}$ & $\begin{array}{c}\text { Fraco } \\
\text { (1) }\end{array}$ & $\begin{array}{l}\text { Moderado } \\
\text { (2) }\end{array}$ & $\begin{array}{l}\text { Forte } \\
\text { (3) }\end{array}$ \\
\hline $\begin{array}{c}\text { Serra Verde, } \\
\text { Cruzeiro de Cerro } \\
\text { Corá, Vale Vulcânico, } \\
\text { Mirante de Santa } \\
\text { Rita, Pico do Totoró, } \\
\text { Morro do Cruzeiro, } \\
\text { Cânion dos } \\
\text { Apertados, Marmitas } \\
\text { do Rio Carnaúba, } \\
\text { Açude Gargalheiras, } \\
\text { Cruzeiro de Acari, } \\
\text { Poço do Arroz, } \\
\text { Monte do Galo, } \\
\text { Xiquexique, Açude } \\
\text { Boqueirão e Mirador }\end{array}$ & $\begin{array}{c}\text { Não há eventos } \\
\text { disponíveis para } \\
\text { a comunidade } \\
\text { que abordem a } \\
\text { questão } \\
\text { ambiental nem } \\
\text { há a participação } \\
\text { das escolas na } \\
\text { causa }\end{array}$ & $\begin{array}{c}\text { Há eventos } \\
\text { esporádicos } \\
\text { sobre o meio } \\
\text { ambiente, } \\
\text { mas não há } \\
\text { articulação } \\
\text { das escolas } \\
\text { para exercer } \\
\text { um trabalho } \\
\text { paralelo }\end{array}$ & $\begin{array}{l}\text { Há eventos } \\
\text { esporádicos } \\
\text { sobre o } \\
\text { meio } \\
\text { ambiente e } \\
\text { as escolas } \\
\text { participam }\end{array}$ & $\begin{array}{l}\text { Há eventos gratuitos } \\
\text { regularmente que } \\
\text { tratam de assuntos } \\
\text { relacionados ao meio } \\
\text { ambiente do local, } \\
\text { além da articulação e } \\
\text { participação das } \\
\text { escolas nesses } \\
\text { eventos }\end{array}$ \\
\hline \multirow[b]{2}{*}{ Geossítio } & \multicolumn{4}{|c|}{ Pesos } \\
\hline & $\begin{array}{l}\text { Inexistente } \\
\text { (0) }\end{array}$ & $\begin{array}{l}\text { Fraco } \\
\text { (1) }\end{array}$ & $\begin{array}{l}\text { Moderado } \\
(2)\end{array}$ & $\begin{array}{l}\text { Forte } \\
\text { (3) }\end{array}$ \\
\hline Mina Brejuí & $\begin{array}{c}\text { Não há eventos } \\
\text { disponíveis para } \\
\text { a comunidade } \\
\text { que abordem a } \\
\text { questão } \\
\text { ambiental nem } \\
\text { há a participação } \\
\text { das escolas na } \\
\text { causa }\end{array}$ & $\begin{array}{c}\text { Há eventos } \\
\text { esporádicos } \\
\text { sobre o meio } \\
\text { ambiente, } \\
\text { mas não há } \\
\text { articulação } \\
\text { das escolas } \\
\text { para exercer } \\
\text { um trabalho } \\
\text { paralelo }\end{array}$ & $\begin{array}{l}\text { Há eventos } \\
\text { esporádicos } \\
\text { sobre o } \\
\text { meio } \\
\text { ambiente e } \\
\text { as escolas } \\
\text { participam }\end{array}$ & $\begin{array}{l}\text { Há eventos gratuitos } \\
\text { regularmente que } \\
\text { tratam de assuntos } \\
\text { relacionados ao meio } \\
\text { ambiente do local, } \\
\text { além da articulação e } \\
\text { participação das } \\
\text { escolas nesses } \\
\text { eventos }\end{array}$ \\
\hline
\end{tabular}

De acordo com o critério de Gestão dos Resíduos Sólidos, os entrevistados apontam nos geossítios Serra Verde, Cruzeiro de Cerro Corá, Morro do Cruzeiro, Açude Boqueirão, Monte do Galo "podemos ver a dispersão de lixo, pois como fica afastado do centro urbano não passa 
caminhão por lá". Assim, foi atribuído a esse critério um nível Fraco (Quadro 11). Contudo, nos geossítios Mina Brejuí, Açude Gargalheiras, Cruzeiro de Acari teve uma situação de nível Forte (Quadro 11), com isso os entrevistados colocam que "há adoção dessas práticas como, por exemplo, o reaproveitamento dos entulhos, é uma forma de sustentabilidade ambiental, pois reduzem os impactos no ambiente; de sustentabilidade econômica, sendo vista como uma segunda alternativa de renda; e, também, de sustentabilidade social proporcionando uma melhoria na qualidade de vida da comunidade". Nos demais geossítios Vale Vulcânico, Mirante Santa Rita, Pico Totoró, Cânion dos Apertados, Poço do Arroz, Marmitas do Rio Carnaúba, Xiquexique se teve nível Inexistente (Quadro 11), porque não há coleta nos locais devida o afastamento do centro urbano e do acesso.

Quadro 11: Resultados obtidos para o indicador Gestão do Meio Ambiente - Gestão dos Resíduos Sólidos.

Table 11: Results for the management indicator of the Environment - Solid Waste Management.

\begin{tabular}{|c|c|c|c|c|}
\hline \multicolumn{5}{|c|}{$\begin{array}{l}\text { GESTÃO DO MEIO AMBIENTE } \\
\text { Gestão dos Resíduos Sólidos }\end{array}$} \\
\hline \multirow[b]{2}{*}{ Geossítios } & \multicolumn{4}{|c|}{$\begin{array}{ll}\text { Pesos } \\
\end{array}$} \\
\hline & $\begin{array}{c}\text { Inexistente } \\
(0)\end{array}$ & $\begin{array}{l}\text { Fraco } \\
(1)\end{array}$ & $\begin{array}{l}\text { Moderado } \\
\text { (2) }\end{array}$ & $\begin{array}{l}\text { Forte } \\
(3)\end{array}$ \\
\hline $\begin{array}{l}\text { Vale Vulcânico, } \\
\text { Mirante Santa } \\
\text { Rita, Pico Totoró, } \\
\text { Cânion dos } \\
\text { Apertados, Poço } \\
\text { do Arroz, } \\
\text { Marmitas do Rio } \\
\text { Carnaúba, } \\
\text { Xiquexique }\end{array}$ & $\begin{array}{l}\text { Não há eventos } \\
\text { disponíveis para } \\
\text { a comunidade } \\
\text { que abordem a } \\
\text { questão } \\
\text { ambiental nem } \\
\text { há a participação } \\
\text { das escolas na } \\
\text { causa }\end{array}$ & $\begin{array}{c}\text { Há eventos } \\
\text { esporádicos } \\
\text { sobre o meio } \\
\text { ambiente, mas } \\
\text { não há } \\
\text { articulação das } \\
\text { escolas para } \\
\text { exercer um } \\
\text { trabalho } \\
\text { paralelo } \\
\end{array}$ & $\begin{array}{l}\text { Há eventos } \\
\text { esporádicos } \\
\text { sobre o } \\
\text { meio } \\
\text { ambiente e } \\
\text { as escolas } \\
\text { participam }\end{array}$ & $\begin{array}{l}\text { Há eventos gratuitos } \\
\text { regularmente que } \\
\text { tratam de assuntos } \\
\text { relacionados ao meio } \\
\text { ambiente do local, } \\
\text { além da articulação e } \\
\text { participação das } \\
\text { escolas nesses } \\
\text { eventos }\end{array}$ \\
\hline \multirow[b]{2}{*}{ Geossítios } & \multicolumn{4}{|c|}{ Pesos } \\
\hline & $\begin{array}{l}\text { Inexistente } \\
(0)\end{array}$ & $\begin{array}{c}\text { Fraco } \\
(1)\end{array}$ & $\begin{array}{l}\text { Moderado } \\
\text { (2) }\end{array}$ & $\begin{array}{c}\text { Forte } \\
\text { (3) }\end{array}$ \\
\hline $\begin{array}{c}\text { Serra Verde, } \\
\text { Cruzeiro de } \\
\text { Cerro Corá, } \\
\text { Morro do } \\
\text { Cruzeiro, Açude } \\
\text { Boqueirão, } \\
\text { Monte do Galo }\end{array}$ & $\begin{array}{c}\text { Não há eventos } \\
\text { disponíveis para } \\
\text { a comunidade } \\
\text { que abordem a } \\
\text { questão } \\
\text { ambiental nem } \\
\text { há a participação } \\
\text { das escolas na } \\
\text { causa }\end{array}$ & $\begin{array}{l}\text { Há eventos } \\
\text { esporádicos } \\
\text { sobre o meio } \\
\text { ambiente, mas } \\
\text { não há articu- } \\
\text { lação das esco- } \\
\text { las para exercer } \\
\text { um trabalho } \\
\text { paralelo }\end{array}$ & $\begin{array}{l}\text { Há eventos } \\
\text { esporádicos } \\
\text { sobre o } \\
\text { meio } \\
\text { ambiente e } \\
\text { as escolas } \\
\text { participam }\end{array}$ & $\begin{array}{l}\text { Há eventos gratuitos } \\
\text { regularmente que } \\
\text { tratam de assuntos } \\
\text { relacionados ao meio } \\
\text { ambiente do local, } \\
\text { além da articulação e } \\
\text { participação das } \\
\text { escolas nesses } \\
\text { eventos }\end{array}$ \\
\hline \multirow[b]{2}{*}{ Geossítios } & \multicolumn{4}{|c|}{ Pesos } \\
\hline & $\begin{array}{c}\text { Inexistente } \\
(0)\end{array}$ & $\begin{array}{c}\text { Fraco } \\
(1)\end{array}$ & $\begin{array}{c}\text { Moderado } \\
\text { (2) }\end{array}$ & $\begin{array}{c}\text { Forte } \\
\text { (3) }\end{array}$ \\
\hline $\begin{array}{c}\text { Mina Brejuí, } \\
\text { Açude } \\
\text { Gargalheiras, } \\
\text { Cruzeiro de Acari }\end{array}$ & $\begin{array}{c}\text { Não há eventos } \\
\text { disponíveis para } \\
\text { a comunidade } \\
\text { que abordem a } \\
\text { questão } \\
\text { ambiental nem } \\
\text { há a participação } \\
\text { das escolas na } \\
\text { causa }\end{array}$ & $\begin{array}{c}\text { Há eventos } \\
\text { esporádicos } \\
\text { sobre o meio } \\
\text { ambiente, mas } \\
\text { não há articula- } \\
\text { ção das escolas } \\
\text { para exercer um } \\
\text { trabalho } \\
\text { paralelo }\end{array}$ & $\begin{array}{l}\text { Há eventos } \\
\text { esporádicos } \\
\text { sobre o } \\
\text { meio } \\
\text { ambiente e } \\
\text { as escolas } \\
\text { participam }\end{array}$ & $\begin{array}{l}\text { Há eventos gratuitos } \\
\text { regularmente que } \\
\text { tratam de assuntos } \\
\text { relacionados ao meio } \\
\text { ambiente do local, } \\
\text { além da articulação e } \\
\text { participação das } \\
\text { escolas nesses } \\
\text { eventos }\end{array}$ \\
\hline
\end{tabular}


No critério Conservação e Gestão do Uso da Água tem-se que, de acordo com a resposta dos entrevistados "os municípios passam por racionamento desde janeiro de 2014, e assim se afetam todos os atrativos naturais de nossa localidade, e essa falta de chuva é problema em todos os meses do ano, pois é um problema da região". Portanto, esse critério obteve nível Fraco (Quadro 12). Vale ressaltar que, apenas o geossítio Mirante Santa Rita alcançou nível Forte, devido ao município de Lagoa Nova ser abastecido por meio da adutora que vem da barragem Armando Ribeiro, da cidade de Açu.

Quadro 12: Resultados obtidos para o indicador Gestão do Meio Ambiente - Conservação e Gestão do Uso da Água.

Table 12: Results for the management indicator of the Environment - Water Conservation and Use Management

\begin{tabular}{|c|c|c|c|c|}
\hline \multicolumn{5}{|c|}{$\begin{array}{c}\text { GESTÃO DO MEIO AMBIENTE } \\
\text { Conservação e Gestão do Uso da Água }\end{array}$} \\
\hline \multirow[b]{2}{*}{ Geossítios } & \multicolumn{4}{|c|}{$\begin{array}{cc} & \text { Pesos } \\
\end{array}$} \\
\hline & $\begin{array}{l}\text { Inexistente } \\
(0)\end{array}$ & $\begin{array}{c}\text { Fraco } \\
(1)\end{array}$ & $\begin{array}{l}\text { Moderado } \\
\text { (2) }\end{array}$ & $\begin{array}{l}\text { Forte } \\
\text { (3) }\end{array}$ \\
\hline $\begin{array}{c}\text { Serra Verde, } \\
\text { Cruzeiro de } \\
\text { Cerro Corá, Vale } \\
\text { Vulcânico, Pico } \\
\text { do Totoró, Morro } \\
\text { do Cruzeiro, } \\
\text { Cânion dos } \\
\text { Apertados, } \\
\text { Marmitas do Rio } \\
\text { Carnaúba, } \\
\text { Açude } \\
\text { Gargalheiras, } \\
\text { Cruzeiro de } \\
\text { Acari, Poço do } \\
\text { Arroz, Monte do } \\
\text { Galo, } \\
\text { Xiquexique, } \\
\text { Açude } \\
\text { Boqueirão, Mina } \\
\text { Brejuí e Mirador }\end{array}$ & $\begin{array}{c}\text { Não há eventos } \\
\text { disponíveis para } \\
\text { a comunidade } \\
\text { que abordem a } \\
\text { questão } \\
\text { ambiental nem } \\
\text { há a participação } \\
\text { das escolas na } \\
\text { causa }\end{array}$ & $\begin{array}{c}\text { Há eventos } \\
\text { esporádicos } \\
\text { sobre o meio } \\
\text { ambiente, mas } \\
\text { não há } \\
\text { articulação } \\
\text { das escolas } \\
\text { para exercer } \\
\text { um trabalho } \\
\text { paralelo }\end{array}$ & $\begin{array}{l}\text { Há eventos } \\
\text { esporádicos } \\
\text { sobre o } \\
\text { meio } \\
\text { ambiente e } \\
\text { as escolas } \\
\text { participam }\end{array}$ & $\begin{array}{l}\text { Há eventos gratuitos } \\
\text { regularmente que } \\
\text { tratam de assuntos } \\
\text { relacionados ao } \\
\text { meio ambiente do } \\
\text { local, além da } \\
\text { articulação e } \\
\text { participação das } \\
\text { escolas nesses } \\
\text { eventos }\end{array}$ \\
\hline & \multicolumn{4}{|c|}{ Pesos } \\
\hline Geossítio & $\begin{array}{c}\text { Inexistente } \\
(0)\end{array}$ & $\begin{array}{c}\text { Fraco } \\
(1)\end{array}$ & $\begin{array}{c}\text { Moderado } \\
(2)\end{array}$ & $\begin{array}{c}\text { Forte } \\
(3) \\
\end{array}$ \\
\hline $\begin{array}{c}\text { Mirante Santa } \\
\text { Rita }\end{array}$ & $\begin{array}{l}\text { Não há eventos } \\
\text { disponíveis para } \\
\text { a comunidade } \\
\text { que abordem a } \\
\text { questão } \\
\text { ambiental nem } \\
\text { há a participação } \\
\text { das escolas na } \\
\text { causa }\end{array}$ & $\begin{array}{c}\text { Há eventos } \\
\text { esporádicos } \\
\text { sobre o meio } \\
\text { ambiente, mas } \\
\text { não há } \\
\text { articulação } \\
\text { das escolas } \\
\text { para exercer } \\
\text { um trabalho } \\
\text { paralelo }\end{array}$ & $\begin{array}{c}\text { Há eventos } \\
\text { esporádicos } \\
\text { sobre o } \\
\text { meio } \\
\text { ambiente e } \\
\text { as escolas } \\
\text { participam }\end{array}$ & $\begin{array}{l}\text { Há eventos gratuitos } \\
\text { regularmente que } \\
\text { tratam de assuntos } \\
\text { relacionados ao } \\
\text { meio ambiente do } \\
\text { local, além da } \\
\text { articulação e } \\
\text { participação das } \\
\text { escolas nesses } \\
\text { eventos }\end{array}$ \\
\hline
\end{tabular}

Por fim, o critério Saneamento e Gestão dos Recursos Hídricos alcançou o nível Inexistente (Quadro 13) nos geossítios Serra Verde, Vale Vulcânico, Pico Totoró, Cânions dos Apertados, Açude Gargalheiras, 
Cruzeiro de Acari, Poço do Arroz, Marmitas do Rio Carnaúba, Mirador e Xiquexique devido "a falta de moradores nos seus arredores fazendo com que não exista saneamento no local", de acordo com entrevistado. Os geossítios Cruzeiro de Cerro Corá, Mirante de Santa Rita, Morro do Cruzeiro, Açude Boqueirão obtiveram nível Fraco (Quadro 13), como expõe os entrevistados "não são todos os moradores dos arredores desses locais que possuem saneamento básico, e isso, faz com que sua destinação seja feita de forma precária, expondo um odor perto dos bares existentes, devido também à questão do uso da pesca". Os geossítios Mina Brejuí e Monte do Galo obtiveram nível Moderado (Quadro 13), onde o saneamento é realizado pela população do entorno desses locais, mas sua destinação e tratamento não são adequados.

Quadro 13: Resultados obtidos para o indicador Gestão do Meio Ambiente - Saneamento e Gestão dos Recursos Hídricos.

Table 13: Results for the management indicator of the Environment - Sanitation and Water Management.

\begin{tabular}{|c|c|c|c|c|}
\hline \multicolumn{5}{|c|}{$\begin{array}{l}\text { GESTÃO DO MEIO AMBIENTE } \\
\text { Saneamento e Gestão dos Recursos Hídricos }\end{array}$} \\
\hline \multirow[b]{2}{*}{ Geossítios } & \multicolumn{4}{|c|}{$\begin{array}{c}\text { Pesos } \\
\end{array}$} \\
\hline & $\begin{array}{l}\text { Inexistente } \\
(0)\end{array}$ & $\begin{array}{c}\text { Fraco } \\
(1)\end{array}$ & $\begin{array}{l}\text { Moderado } \\
(2)\end{array}$ & $\begin{array}{l}\text { Forte } \\
\text { (3) }\end{array}$ \\
\hline $\begin{array}{c}\text { Serra Verde, Vale } \\
\text { Vulcânico, Pico Totoró, } \\
\text { Cânions dos } \\
\text { Apertados, Açude } \\
\text { Gargalheiras, Cruzeiro } \\
\text { de Acari, Poço do } \\
\text { Arroz, Marmitas do Rio } \\
\text { Carnaúba, Mirador e } \\
\text { Xiquexique }\end{array}$ & $\begin{array}{l}\text { Não há eventos } \\
\text { disponíveis para } \\
\text { a comunidade } \\
\text { que abordem a } \\
\text { questão ambien- } \\
\text { tal nem há a } \\
\text { participação das } \\
\text { escolas }\end{array}$ & $\begin{array}{l}\text { Há eventos } \\
\text { esporádicos sobre } \\
\text { o meio ambiente, } \\
\text { mas não há } \\
\text { articulação das } \\
\text { escolas para } \\
\text { exercer um } \\
\text { trabalho paralelo }\end{array}$ & $\begin{array}{l}\text { Há eventos } \\
\text { esporádicos } \\
\text { sobre o } \\
\text { meio } \\
\text { ambiente e } \\
\text { as escolas } \\
\text { participam }\end{array}$ & $\begin{array}{l}\text { Há eventos gratui- } \\
\text { tos regularmente } \\
\text { que tratam de as- } \\
\text { suntos relacionados } \\
\text { ao meio ambiente } \\
\text { do local, além da } \\
\text { articulação e partici- } \\
\text { pação das escolas } \\
\text { nesses eventos }\end{array}$ \\
\hline \multirow[b]{2}{*}{ Geossítios } & \multicolumn{4}{|c|}{ Pesos } \\
\hline & $\begin{array}{c}\text { Inexistente } \\
(0)\end{array}$ & $\begin{array}{l}\text { Fraco } \\
(1)\end{array}$ & $\begin{array}{l}\text { Moderado } \\
(2)\end{array}$ & $\begin{array}{c}\text { Forte } \\
\text { (3) }\end{array}$ \\
\hline $\begin{array}{c}\text { Cruzeiro de Cerro } \\
\text { Corá, Mirante de Santa } \\
\text { Rita, Morro do } \\
\text { Cruzeiro, Açude } \\
\text { Boqueirão }\end{array}$ & $\begin{array}{c}\text { Não há eventos } \\
\text { disponíveis para } \\
\text { a comunidade } \\
\text { que abordem a } \\
\text { questão ambien- } \\
\text { tal nem há a } \\
\text { participação das } \\
\text { escolas na } \\
\text { causa }\end{array}$ & $\begin{array}{c}\text { Há eventos } \\
\text { esporádicos sobre } \\
\text { o meio ambiente, } \\
\text { mas não há } \\
\text { articulação das } \\
\text { escolas para } \\
\text { exercer um } \\
\text { trabalho paralelo }\end{array}$ & $\begin{array}{l}\text { Há eventos } \\
\text { esporádicos } \\
\text { sobre o } \\
\text { meio } \\
\text { ambiente e } \\
\text { as escolas } \\
\text { participam }\end{array}$ & $\begin{array}{l}\text { Há eventos gratui- } \\
\text { tos regularmente } \\
\text { que tratam de as- } \\
\text { suntos relacionados } \\
\text { ao meio ambiente } \\
\text { do local, além da } \\
\text { articulação e partici- } \\
\text { pação das escolas } \\
\text { nesses eventos }\end{array}$ \\
\hline \multirow[b]{2}{*}{ Geossítios } & \multicolumn{4}{|c|}{ Pesos } \\
\hline & $\begin{array}{c}\text { Inexistente } \\
(0)\end{array}$ & $\begin{array}{c}\text { Fraco } \\
(1)\end{array}$ & $\begin{array}{c}\text { Moderado } \\
(2)\end{array}$ & $\begin{array}{c}\text { Forte } \\
\text { (3) }\end{array}$ \\
\hline $\begin{array}{l}\text { Mina Brejuí e Monte do } \\
\text { Galo }\end{array}$ & $\begin{array}{l}\text { Não há eventos } \\
\text { disponíveis para } \\
\text { a comunidade } \\
\text { que abordem a } \\
\text { questão ambien- } \\
\text { tal nem há a } \\
\text { participação das } \\
\text { escolas }\end{array}$ & $\begin{array}{c}\text { Há eventos } \\
\text { esporádicos sobre } \\
\text { o meio ambiente, } \\
\text { mas não há articu- } \\
\text { lação das escolas } \\
\text { para exercer um } \\
\text { trabalho paralelo }\end{array}$ & $\begin{array}{c}\text { Há eventos } \\
\text { esporádicos } \\
\text { sobre o } \\
\text { meio } \\
\text { ambiente e } \\
\text { as escolas } \\
\text { participam }\end{array}$ & $\begin{array}{l}\text { Há eventos gratui- } \\
\text { tos regularmente } \\
\text { que tratam de as- } \\
\text { suntos relacionados } \\
\text { ao meio ambiente } \\
\text { do local, além da } \\
\text { articulação e partici- } \\
\text { pação das escolas } \\
\text { nesses eventos }\end{array}$ \\
\hline
\end{tabular}


Diante dos dados analisados em cada dimensão ambiental e seus respectivos critérios, os resultados finais para cada geossítio pesquisado estão representados na Figura 3 e na Tabela 1, correspondendo às porcentagens atingidas e seus diferentes níveis de satisfação.

Diante do exposto na Figura 3 e Tabela 1 o geossítio Cânion dos Apertados (Currais Novos) encontra-se numa situação insatisfatória quanto a sua dimensão ambiental da sustentabilidade. Assim, esse local está buscando entrar na fase de exploração e envolvimento, que segundo Falcão (2010) é a fase de exploração de um destino, correspondendo a uma situação na qual o número de visitantes é reduzido e a infraestrutura inexistente. Assim, locais que estão se encaminhando para entrar nessa fase apresentam potencial para o desenvolvimento da atividade turística devido a seu atrativo natural, porém, não há estruturação nem planejamento da atividade turística. Já o estágio de envolvimento representa o momento em que se está trabalhando a definição do mercado, e com isso, começa a ser oferecida uma melhor infraestrutura, assim como, uma acessibilidade ao atrativo.

Ressalta-se que, na fase de exploração, o destino ainda não possui facilidades específicas para uso turístico, sendo que os turistas utilizam as facilidades locais. Nessa fase, há um grande contato entre turistas e a comunidade local. Na fase de envolvimento, a comunidade local participa do processo turístico e começa a disponibilizar serviços aos turistas. Há uma pressão para que o setor público disponibilize e/ou melhore a infraestrutura de acesso e outras facilidades necessárias para o turista (BUTLER, 1980; ALVARES, 2008).

Sendo assim, a participação da comunidade não deve ser focada apenas no processo de tomada de decisão ou escolha dos representantes públicos. É também necessário que a comunidade desenvolva a capacidade de resolver seus próprios problemas (BARTHOLO, 2009). É capaz, ainda, de negociar e mediar os conflitos de interesses que sempre estarão presentes nos destinos turísticos (BENI, 2006).

Os geossítios Serra Verde (Cerro Corá), Cruzeiro (Cerro Corá), Vale Vulcânico (Cerro Corá), Pico Totoró (Currais Novos), Morro do Cruzeiro (Currais Novos), Cruzeiro de Acari (Acari), Poço do Arroz (Acari), Marmitas do Rio Carnaúba (Acari), Açude Boqueirão (Parelhas), Mirador (Parelhas), Monte do Galo (Carnaúba dos Dantas) e Xiquexique (Carnaúba dos Dantas), diante das pesquisas, se encontram numa situação pouco satisfatória. Isso indica que esses geossítios se encaminham para um estágio denominado de desenvolvimento, ou seja, se tem a definição desses destinos, atentando para atrações e campanhas promocionais para a divulgação desses lugares, e com isso, permitirá um crescimento gradualmente conforme a inserção de visitantes. Em que, nesta fase, o marketing turístico é muito utilizado e há uma mudança significativa em relação à disponibilização de facilidades, investidores não locais entram no mercado provendo facilidades, particularmente, meios de hospedagem, em detrimento da oferta organizada pela comunidade local (BUTLER, 1980; ALVARES, 2008). 
Figura 3: Régua de nível de satisfação para cada geossítio pesquisado.

Figure 3: Ruler level of satisfaction for each searched geosite.

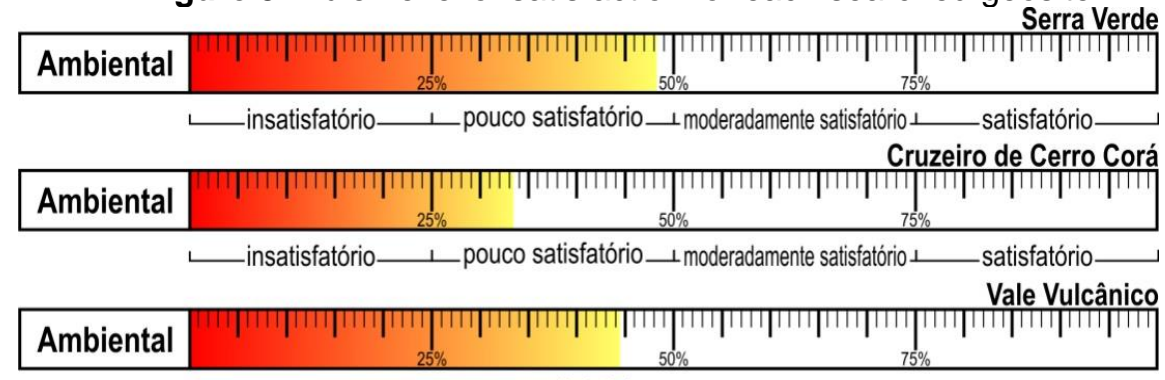

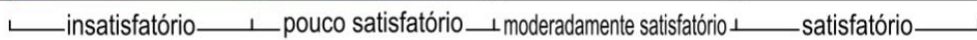
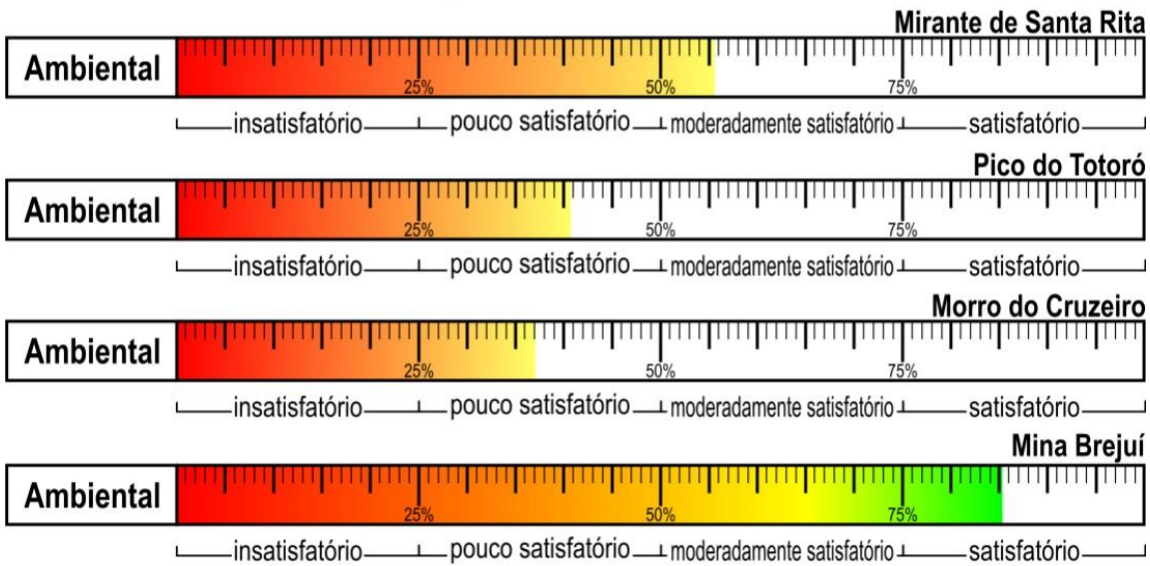

Cânion dos Apertados

\begin{tabular}{|c|c|}
\hline Ambiental & 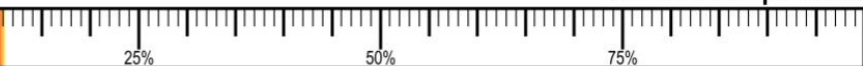 \\
\hline
\end{tabular}

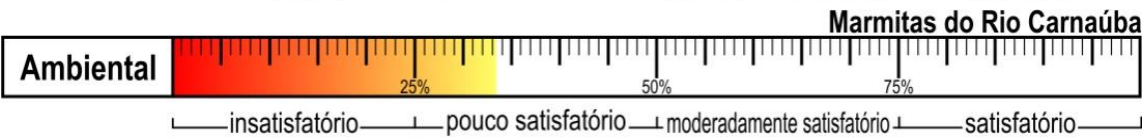

Açude Gargalheiras

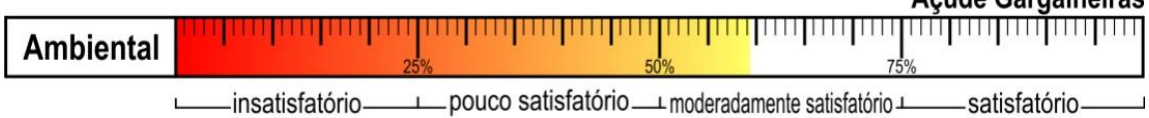

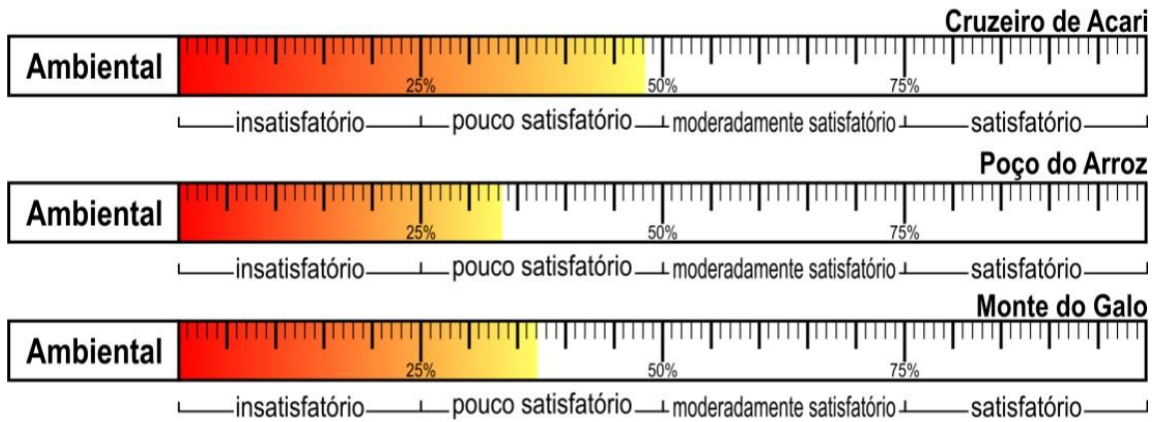

Xiquexique

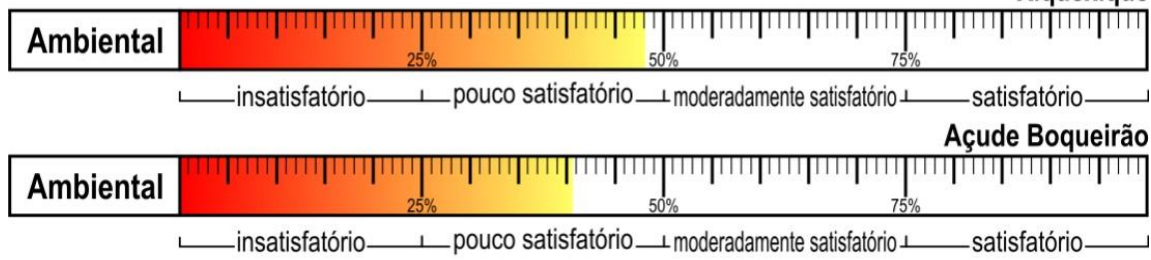

Mirador

\begin{tabular}{|c|c|}
\hline Ambiental & 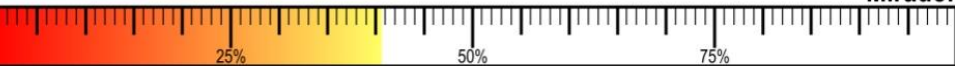 \\
\hline
\end{tabular}

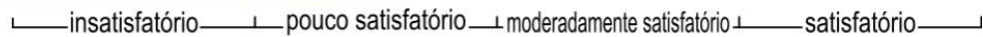


Tabela 1: Nível de satisfação da dimensão ambiental da sustentabilidade dos geossítios do Projeto Geoparque Seridó.

Table 1: Environmental dimension of satisfaction level of sustainability of geosites Geopark Serido Project.

\begin{tabular}{|c|c|c|c|}
\hline Geossítio & Município & $\begin{array}{l}\text { Porcentagem } \\
\text { atingida }\end{array}$ & $\begin{array}{l}\text { Nível de satisfação } \\
\text { alcançado }\end{array}$ \\
\hline Serra Verde & Cerro Corá & $48,15 \%$ & Pouco Satisfatório \\
\hline $\begin{array}{c}\text { Cruzeiro de Cerro } \\
\text { Corá }\end{array}$ & Cerro Corá & $33,33 \%$ & Pouco Satisfatório \\
\hline Vale Vulcânico & Cerro Corá & $44,44 \%$ & Pouco Satisfatório \\
\hline Mirante Santa Rita & Lagoa Nova & $55,55 \%$ & $\begin{array}{l}\text { Moderadamente } \\
\text { Satisfatório }\end{array}$ \\
\hline Pico Totoró & Currais Novos & $40,74 \%$ & Pouco Satisfatório \\
\hline Morro do Cruzeiro & Currais Novos & $37,04 \%$ & Pouco Satisfatório \\
\hline Mina Brejuí & Currais Novos & $85,19 \%$ & Satisfatório \\
\hline Cânion dos Apertados & Currais Novos & $11,11 \%$ & Insatisfatório \\
\hline $\begin{array}{c}\text { Marmitas do Rio } \\
\text { Carnaúba }\end{array}$ & Acari & $33,33 \%$ & Pouco Satisfatório \\
\hline Açude Gargalheiras & Acari & $59,30 \%$ & $\begin{array}{l}\text { Moderadamente } \\
\text { Satisfatório }\end{array}$ \\
\hline Cruzeiro de Acari & Acari & $48,15 \%$ & Pouco Satisfatório \\
\hline Poço do Arroz & Acari & $33,33 \%$ & Pouco Satisfatório \\
\hline Monte do Galo & $\begin{array}{c}\text { Carnaúba dos } \\
\text { Dantas }\end{array}$ & $37,04 \%$ & Pouco Satisfatório \\
\hline Xiquexique & $\begin{array}{c}\text { Carnaúba dos } \\
\text { Dantas }\end{array}$ & $48,15 \%$ & Pouco Satisfatório \\
\hline Açude Boqueirão & Parelhas & $40,74 \%$ & Pouco Satisfatório \\
\hline Mirador & Parelhas & $40,74 \%$ & Pouco Satisfatório \\
\hline
\end{tabular}

Os geossítios Mirante de Santa Rita (Lagoa Nova) e Açude Gargalheiras (Acari) se mostram numa situação moderadamente satisfatória, ou seja, indica que estão se direcionando para uma possível fase de consolidação, que se destaca pela comercialização do destino. Portanto, nessa fase o turismo é importante para a economia local e continua a haver crescimento do número de turistas, no entanto, há um decréscimo na taxa de crescimento turístico. Os destinos investem em propaganda e marketing para atrair mais turistas e sanar problemas relativos à sazonalidade turística (BUTLER, 1980; ALVARES, 2008).

Por fim, o geossítio Mina Brejuí alcançou uma situação satisfatória, indicando que esse local está se encaminhando a fase de estagnação, e assim, se deve começar a buscar medidas para que esse lugar se encaminhe para uma fase de pós-estagnação. Visto que, segundo Falcão (2010, p.34) "a fase de estagnação é o inicio do declínio na quantidade de turistas do destino". Essa fase se caracteriza principalmente pela redução parcial do número de turistas além das capacidades de carga dos atrativos que passam a ser excedidas, acarretando problemas econômicos, sociais e ambientais.

Já a fase do estágio de pós-estagnação consiste em duas possibilidades, a primeira refere-se ao declínio onde o destino perde sua atratividade inicial devido principalmente à degradação dos atrativos naturais resultando diretamente na diminuição expressiva da quantidade de turistas no destino, e à segunda possibilidade do estágio de pós-estagnação 
corresponde ao rejuvenescimento, que é quando o destino passa por uma reestruturação para atrair novamente os visitantes e se busca explorar/criar alguns lugares ainda não utilizados.

\section{Considerações finais}

Sobre a análise ambiental da sustentabilidade nos geossítios do Projeto Geoparque Seridó, nota-se um equilíbrio entre eles, uma vez que apenas um geossítio apresentou resultado insatisfatório, dois geossítios com moderadamente satisfatório e um geossítio satisfatório, enquanto os demais apresentaram níveis pouco satisfatórios. Com base nessas avaliações seria possível afirmar que os geossítios estudados possuem potencial para o turismo ou pelo menos estão caminhando em direção ao desenvolvimento turístico nessa região.

Porém, é importante atentar uma região que pretende trabalhar com seus atrativos naturais por meio da atividade turística necessita do envolvimento de seus atores para transformá-los em produtos turísticos, buscando competitividade, motivando as pessoas a saírem do seu entorno habitual para visitá-los, e assim vivenciar uma nova experiência, pois as pessoas estão cada vez mais procurando destinos que possuam singularidade em seus atrativos e autenticidade em seus produtos oferecidos.

Ressalta-se, porquanto, que o planejamento turístico como observado nas referências citadas ao longo do trabalho é uma variável indispensável para a obtenção do sucesso em qualquer atividade pensada para tal região. Contudo, as observações realizadas nesses municípios evidenciaram que este elemento não é posto em prática de forma pontual, sendo utilizado apenas para suprir a interesses específicos, propiciando o desenvolvimento da atividade turística de forma desarranjada e com pouca responsabilidade ao que se refere à sustentabilidade, nesse ponto ressalta-se a importância de um profissional da área do Turismo no Projeto Geoparque Seridó, para trabalhar justamente o planejamento organizado.

Diante do exposto, a região estudada apresenta problemas no que tange a conservação dos geossítios, assim como, a falta de consciência ambiental. Ficando evidenciado pela ausência de investimentos por parte dos órgãos responsáveis e a falta de consciência da importância da área também das populações locais e dos visitantes.

Esta pesquisa identifica os principais problemas que acarretam nos geossítios do Projeto Geoparque Seridó/RN, assim como, possibilita obter dados da atual conjuntura da atividade turística voltada à geodiversidade nos municípios, e com isso, despertar nos atores direto do turismo local a intenção da elaboração e o planejamento organizado e participativo para promover cada destino turístico, sempre com base nos princípios da sustentabilidade.

Concluiu-se, portanto, que na procura por promover a sustentabilidade atrelada à atividade turística é indispensável que os destinos turísticos sejam avaliados conforme seu contexto e suas demandas 
locais específicas. Ao ponto que, os atores desse processo necessitam procurar se adequar às ações, objetivando o desenvolvimento de acordo com as possibilidades desse destino, em que os sistemas de indicadores devem ser adaptados à realidade local de forma a possibilitar uma prática turística sustentável.

\section{Referências}

ALVARES, D. Avaliação de planos - processo em áreas de desenvolvimento turístico. 2008. Tese (Doutorado Engenharia Civil) - Universidade do Minho, Braga, 263p, 2008.

BARTHOLO, R.S.J. Utilização de indicadores de sustentabilidade na análise de destinos turísticos. Relatório Técnico Científico - CNPQ. Laboratório de Tecnologia e Desenvolvimento Social, UFRJ, Rio de Janeiro, 2009.

BENI, M.C. Análise estrutural do Turismo. 11 ed. São Paulo: Editora Senac, 2006.

BEZERRA, R.C.L.; GONÇALVES, M.I.P.C.; MELO, J.P.P.; GALVÃO, M.N.C.; SILVA, C.T.R.; FEITOSA, J.R.M. (orgs.). Educação ambiental: Edição para professores e gestores. Ceará: URCA, 2011.

BUARQUE, S.C. Construindo o Desenvolvimento Local Sustentável: Metodologia de planejamento". 2a . Rio de Janeiro, Garamond, 2004.

BUTLER, R. The concept of Tourist Aea Cycle of Evolution: Implications for Management of Resources. Canadian Geographer. v.24, p.5-12, 1980.

DELAMARO, M.C.; SAVIOLO, S.; SANTOS, J.H.O.; BURSZTYN, I.; DELAMARO, L.S.L.; D'OLIVEIRA, E.; MUDADO, T. Turismo nas fazendas históricas do Vale do Paraíba Fluminense: um estudo sobre a sustentabilidade. Caderno Virtual de Turismo, v.2, p.11-17, 2002.

FALCÃO, M.C. A sustentabilidade do destino turístico de Fernando de Noronha: Uma análise a partir da abordagem do Ciclo de Vida de áreas turísticas e das dimensões da sustentabilidade. Dissertação (Mestrado em Administração) - Universidade Federal de Pernambuco, Recife, 201p, 2010

FOLADORI, G. Sustentabilidad Alternativa. Urugay: Coleccion Carbichui, 2005.

JACOBI, P. Educação ambiental, cidadania e sustentabilidade. Cadernos de Pesquisa, v.118, p.189-205, 2003.

MARTINS, M. F.; CÂNDIDO, G.A. Índices de desenvolvimento sustentável para localidades: Uma proposta metodológica de construção e análise. In: CÂNDIDO, G.A. (org.). Desenvolvimento Sustentável e Sistemas de Indicadores de Sustentabilidade: Formas de aplicações em contextos geográficos diversos e contingências específicas. Campina Grande: Ed. UFCG, 2010.

NASCIMENTO, M.A.L.; FERREIRA, R.V. Geoparque Seridó (RN). In: SHOBBENHAUS, C.; SILVA, C.R. (Org.). Geoparques do Brasil: Propostas. Rio de Janeiro: CPRM, 2012. 
SACHS, I. Caminhos para o desenvolvimento sustentável. Rio de Janeiro: Garamond, 2009.

Janaína Luciana de Medeiros: Universidade Federal do Rio Grande do Norte, Natal, RN, Brasil.

E-mail: janaina_ufrn_turismo@hotmail.com

Link para o currículo Lattes: http://lattes.cnpq.br/4076979809887772

Marcos Antonio Leite do Nascimento: Universidade Federal do Rio Grande do Norte, Natal, RN, Brasil.

E-mail: caxexa@yahoo.com.br

Link para o currículo Lattes: http://lattes.cnpq.br/5356037408083015

André Riani Costa Perinotto: Universidade Federal do Piauí, Parnaíba, PI, Brasil.

E-mail: perinotto@ufpi.edu.br

Link para o currículo Lattes: http://lattes.cnpq.br/9146688925419493

Data de submissão: 09 de setembro de 2016

Data de recebimento de correções: 14 de junho de 2017

Data do aceite: 14 de junho de 2017

Avaliado anonimamente 